\title{
Measurements of aerosol absorption and scattering in the Mexico City Metropolitan Area during the MILAGRO field campaign: a comparison of results from the $\mathrm{T} 0$ and $\mathrm{T} 1$ sites
}

\author{
N. A. Marley ${ }^{1}$, J. S. Gaffney ${ }^{2}$, T. Castro ${ }^{3}$, A. Salcido ${ }^{4}$, and J. Frederick ${ }^{5}$ \\ ${ }^{1}$ Graduate Institute of Technology, University of Arkansas at Little Rock, Little Rock, AR, USA \\ ${ }^{2}$ Department of Chemistry, University of Arkansas at Little Rock, Little Rock, AR, USA \\ ${ }^{3}$ Centro de Ciencias de la Atmósfera,Universidad Nacional Autónoma de México, México City, México \\ ${ }^{4}$ Instituto de Investigaciones Eléctricas, Gerencia de Sistemas de Calidad Ambiente y Seguridad, Cuernavaca, \\ Morelos, México \\ ${ }^{5}$ Department of Geophysical Sciences, The University of Chicago, Chicago, IL, USA
}

Received: 29 May 2008 - Published in Atmos. Chem. Phys. Discuss.: 3 July 2008

Revised: 4 December 2008 - Accepted: 4 December 2008 - Published: 13 January 2009

\begin{abstract}
In March 2006, a multiagency field campaign was undertaken in Mexico City called the Megacities Initiative: Local and Global Research Observations (MILAGRO). Two of the five field components of the MILAGRO study focused a major part of their efforts on atmospheric particulate emissions from the Mexico City basin and their effects on radiative balance as a function of time, location and processing conditions. As part of these two MILAGRO components, measurements of aerosol optical properties were obtained at a site located in the northern part of Mexico City (T0) and also at a site located $29 \mathrm{~km}$ northwest (T1) to estimate the regional effects of aerosol emissions from the basin.

Measurements of aerosol absorption and scattering for fine mode aerosols were obtained at both sites. Aerosol absorption at $550 \mathrm{~nm}$ was similar at both sites, ranging from 7$107 \mathrm{Mm}^{-1}$ at T0 and from $3-147 \mathrm{Mm}^{-1}$ at T1. Aerosol scattering measured at $550 \mathrm{~nm}$ at $\mathrm{T} 0$ ranged from $16-344 \mathrm{Mm}^{-1}$ while the aerosol scattering values at $\mathrm{T} 1$ were much lower than at $\mathrm{T} 0$ ranging from $2-136 \mathrm{Mm}^{-1}$. Aerosol single scattering albedos (SSAs) were calculated at $550 \mathrm{~nm}$ for the fine mode aerosols at both sites using these data. The SSAs at T0 ranged from 0.47-0.92 while SSAs at T1 ranged from 0.35-
\end{abstract}

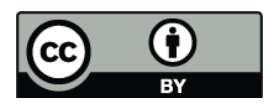

Correspondence to: J. S. Gaffney (jsgaffney@ualr.edu)
0.86 . The presence of these highly absorbing fine aerosols in the lower atmosphere of the Mexico City area will result in a positive climate forcing and a local warming of the boundary layer in the region.

Broadband UVB intensity was found to be higher at site T0, with an average of $64 \mu \mathrm{W} / \mathrm{cm}^{2}$ at solar noon, than at site $\mathrm{T} 1$, which had an average of $54 \mu \mathrm{W} / \mathrm{cm}^{2}$ at solar noon. Comparisons of clear-sky modeled UVB intensities with the simultaneous UVB measurements obtained at sites T0 and $\mathrm{T} 1$ for cloudless days indicate a larger diffuse radiation field at site $\mathrm{T} 0$ than at site $\mathrm{T} 1$. The determination of aerosol Ångstrom scattering coefficients at T0 suggests that this is due to the predominance of aerosols in the size range of 0.3 micron, which leads to scattering of UVB radiation peaked in the forward direction and to an enhanced UVB radiation observed at ground level. This enhancement of the UVB diffuse radiation field would explain the enhanced photochemistry observed in the Mexico City area despite the reduction in UVB anticipated from light absorbing species.

\section{Introduction}

Megacities, large urban and suburban centers whose populations exceed ten million inhabitants, are steadily increasing worldwide with the most rapid growth in the tropical

Published by Copernicus Publications on behalf of the European Geosciences Union. 
areas of South America and Asia. In 1800 only $3 \%$ of the world's population lived in urban areas. This increased to $47 \%$ by the end of the 20th century. In 1950 there were 83 cities with populations exceeding one million and New York City was the only megacity (UNEP/WHO, 1992). By 2007 there were 468 urban centers of more than one million and of these 14 are classified as megacities with the largest metropolitan complexes centered at Tokyo, Japan, and Mexico City, Mexico (Molina and Molina, 2002). If this trend continues, the world's urban populations will double every 38 years and within the next 10 to 15 years it is predicted that there will be more than 30 megacities worldwide.

The Mexico City metropolitan area (MCMA) is the largest urban center in North America and the second largest megacity worldwide. It occupies $\sim 3540 \mathrm{~km}^{2}$ with a population of $\sim 19$ million (CAM, 2002). In general, megacities suffer from poor air quality due to the cumulative effects of rapid population growth and industrialization accompanied with increased traffic densities and total energy consumption. However, the topography of the MCMA also acts to exacerbate the poor air quality (Fast et al., 2007; Fast and Zhong, 1998; Doran et al., 1998) as Mexico City is located in a basin on the central Mexican plateau at an altitude of $2240 \mathrm{~m}$ and latitude of $19^{\circ} \mathrm{N}$. The basin is surrounded on the west, south, and east by mountain ranges that rise up to $1000-3000 \mathrm{~m}$ above the basin floor. This topography serves to inhibit dispersion of emissions within the basin during the early morning hours and the high levels of incoming solar radiation at this latitude and elevation promotes atmospheric photochemical reactions that rapidly form secondary pollutants (Whiteman et al., 2000).

Due to the elevation and topography of Mexico City, the height of the boundary layer may reach up to $2-4 \mathrm{~km}$ above the surface (Raga et al., 2001a; de Foy et al., 2007). Therefore, pollutants are emitted from the basin at altitudes that are considered to be free troposphere elsewhere and are expected to travel long distances affecting the surrounding regions (Gaffney and Marley, 1998; Williams et al., 2002). Modeling results have indicated that the effects of this exported pollution can impact background levels $300 \mathrm{~km}$ or more from the urban area (Barth and Church, 1999; Whiteman et al., 2000). Indeed, past studies have found that the Mexico City air pollutants are typically vented during the late afternoon on a daily basis (Gaffney and Marley, 1998; Whiteman et al., 2000)

Past studies in the Mexico City area have estimated that emissions from the basin contribute 15 megatons of fine aerosol $\left(\mathrm{PM}_{2.5}\right)$ per year to the surrounding regions (Gaffney et al., 1999). This fine aerosol was found to be composed of approximately $32 \%$ organic carbon (OC), $15 \%$ elemental carbon (EC), $10 \%$ ammonium nitrate and $20 \%$ ammonium sulfate by elemental and thermal/optical methods (Chow et al., 1993, 2001, 2002; Vega et al., 2004). More recently, in 2003 the composition of fine aerosols was found to be $11 \%$ black carbon (BC), 32\% OC, 13\% ammonium nitrate, and
$14 \%$ ammonium sulfate by aerosol mass spectrometry and optical attenuation methods (Salcedo et al., 2006; Aiken et al., 2008). This is an indication that although the emissions of reactive hydrocarbon have been reduced in the city due to the significant number of newer vehicles with catalytic converters that have replaced older higher emission vehicles, the aerosol composition has not changed significantly likely due to the lack of controls on diesel vehicles and biomass burning in the region (Marley et al., 2007). Thus, while air quality and ozone production has improved, Mexico City and 25 other megacities continue to be a major source of black carbon aerosols, which can be an important species in determining regional radiative balance and climate.

While sulfate is well known as an important light scattering aerosol species contributing to atmospheric cooling (Charlson et al., 1992), BC and associated OC (including secondary organic aerosol, SOA) have more recently gained attention as major light absorbing aerosol species exerting a positive radiative forcing and reinforcing the atmospheric warming due to increases in the greenhouse gases (Jacobson, 2002; Ramanathan et al., 2005). Some model calculations suggest that the contribution of carbon soot aerosols to global warming may be as much as $0.3-0.4^{\circ} \mathrm{C}$, rivaling the contributions from atmospheric methane (Jacobson, 2004; Chung and Seinfeld, 2005). The ultimate climate effects from carbon aerosols will depend on their physical and chemical properties, as well as their residence times and distributions in the atmosphere (Jacobson, 2001).

The presence of the highly absorbing BC aerosols in Mexico City leads to a reduction in overall solar flux of $17.6 \%$ locally (Raga et al., 2001b). The mass of these absorbing aerosols exported from this megacity into the surrounding region is estimated to be 6.000 metric tons per day or 2 megatons per year of BC (Gaffney et al., 1999). Since freshly emitted BC aerosols are hydrophobic, they are expected to be more resistant to washout and have longer lifetimes than more hygroscopic aerosols such as sulfate and nitrate (Gaffney and Marley, 2005; Dua et al., 1999). In addition, since the aerosols emitted from the Mexico City basin are introduced into the atmosphere at higher altitudes, they are assumed to have longer lifetimes than similar aerosols released at lower altitudes (Raga et al., 2001b). The MCMA is therefore a major source of $\mathrm{BC}$ aerosols to the surrounding regions and the release of these highly absorbing aerosols will have an impact on the radiative balance and climate on a regional scale.

The influences of aerosols on climate are much more complex than those of the greenhouse gasses (Schwartz and Buseck, 2000). Aerosol composition is highly variable, with different species present within the same particle, due to the different sources, production mechanisms and atmospheric transformations (Pósfai et al., 1999). In addition, these different aerosol species can be either internally or externally mixed within the particle yielding different optical and microphysical properties and different radiative effects (Pósfai 
et al., 1999; Schnaiter et al., 2005). Aerosol distributions are also variable both spatially and temporally and although aerosol lifetimes are much shorter than those of the greenhouse gases, estimates of their atmospheric residence times range from less than a day to more than a month resulting in transport distances from a few miles to hemispheric scales (Marley et al., 2000; Williams et al., 2002). This variability in composition and distributions makes it difficult to quantify the aerosol impacts on climate and to represent these effects in climate models.

In order to better understand the evolution and transport of pollutant aerosols and gases from emissions in the Mexico City basin and their resulting impacts on regional climate, a multiagency field campaign was undertaken called the Megacities Initiative: Local and Global Research Observations (MILAGRO). The MILAGRO study was composed of five collaborative field experiments. Two of the components of the MILAGRO study focused a major part of their efforts on aerosol emissions. The Megacity Aerosol Experiment, Mexico City 2006 (MAX-Mex) was sponsored by the US Department of Energy (DOE) to investigate the direct radiative effect of aerosols in the Mexico City plume as a function of time, location and processing conditions. The MCMA-2006 study, supported by various Mexican institutions, the US National Science Foundation (NSF) and the DOE, deployed ground based instrumentation to examine fine particles and secondary aerosol precursor gas emissions within the Mexico City Basin. As part of these two MILAGRO components, aerosol scattering and absorption measurements were obtained at a site located at the Instituto Mexicano del Petróleo (IMP- Mexican Petroleum Institute), in the northwestern part of the Mexico City center. This site, known as T0, was chosen to represent the fresh emissions within the MCMA. Measurements were also obtained at the Universidad Tecnológica de Tecamac (Technological University of Tecamac), located approximately $29 \mathrm{~km}$ northwest of T0. This site, known as T1, was expected to represent a mixture of both fresh and aged pollutants as they exit the basin.

The evolution of absorbing aerosols downwind of Mexico City has been described previously in a comparison of measurements obtained at site $\mathrm{T} 1$ with those obtained at site T2 (Rancho La Bisnaga), located approximately $35 \mathrm{~km}$ northnortheast of T1 (Doran et al., 2007, 2008; Doran, 2007). This study focused primarily on the changes in the carbonaceous aerosol composition and the resulting effects on the aerosol mass specific absorption coefficients. It was concluded from this work that emission sources outside the MCMA, including biomass-burning sources, are important contributors to the regional aerosol burden. Other aerosol studies conducted in the Mexico City area have reported similar conclusions (Kleinman et al., 2008; Molina et al., 2007; Stone et al., 2008; Yokelson et al., 2007; DeCarlo et al., 2008; Salcedo et al., 2006).
Presented here is a comparison of measurements of aerosol absorption and aerosol scattering at $550 \mathrm{~nm}$ obtained at sites $\mathrm{T} 0$ and T1 during the MILAGRO campaign. In addition, the mass specific aerosol absorption coefficients were calculated at $550 \mathrm{~nm}$ by using total carbon (TC) measurements taken from high-volume quartz filters. These results are compared with absorption coefficients reported previously by Doran et al. (2007). Also reported here is a comparison of UVB radiation measurements obtained simultaneously at sites $\mathrm{T} 0$ and $\mathrm{T} 1$, under cloudless conditions, with clear sky modeled UVB values. These data are discussed with regard to the light scattering and absorption measurements obtained at both sites.

\section{Experimental methods}

\subsection{Sample Sites}

\subsubsection{Site T0}

Measurements were obtained from 10 March (day 69) to 29 March (day 88) 2006 at the Instituto Mexicano del Petróleo (IMP) laboratories [Mexico, D. F.]. This site, known as T0, is located in the north central part of Mexico City at latitude $19^{\circ} 29^{\prime} \mathrm{N}$, longitude $99^{\circ} 09^{\prime} \mathrm{W}$, and at an altitude of $2240 \mathrm{~m}$ above sea level. The IMP complex is a campus of 33 buildings located in an industrial and commercial area of Mexico City surrounded by streets that are very heavily trafficked by light duty vehicles and diesel buses. The nearest major roads are approximately $300 \mathrm{~m}$ away from the measurement site.

Relative humidity and rain intensity at site $\mathrm{T} 0$ during the study are shown in Fig. 1 (top). Rain events occurred during the last week of the study period, 23-28 March (days 82-87). Daily maximum relative humidity ranged from a low of $35 \%$ during the first week to a high of $89 \%$ during the last week of March 2006. Winds ranged from 0.1 to $9 \mathrm{~m} / \mathrm{s}$ with an average of $2 \mathrm{~m} / \mathrm{s}$ from the south, southwest.

\subsubsection{Site T1}

Measurements were also obtained from 1 March (day 60) to 29 March (day 88) 2006 at the Technological University of Tecamac, State of Mexico, $30 \mathrm{~km}$ north of Mexico City. This site, known as $\mathrm{T} 1$, is at latitude $19^{\circ} 43^{\prime} \mathrm{N}$ and longitude $98^{\circ} 58^{\prime} \mathrm{W}$ at an altitude of $2340 \mathrm{~m}$ a.s.l. Tecamac has a recorded population of 172410 , as of the 2000 census, and is primarily commercial with a total of 3070 small businesses, of which 1923 are food related. The principal mode of transportation in the area consists of light duty vehicles, and small diesel buses. The main transportation route is public road \# 85, which runs south to north from Mexico City to Pachuca. The municipality of Pachuca, which is located $94 \mathrm{~km}$ northeast of Mexico City and $64 \mathrm{~km}$ northeast of Tecamac, is the capital of the state of Hidalgo with a recorded population of 267751 in 2005. 

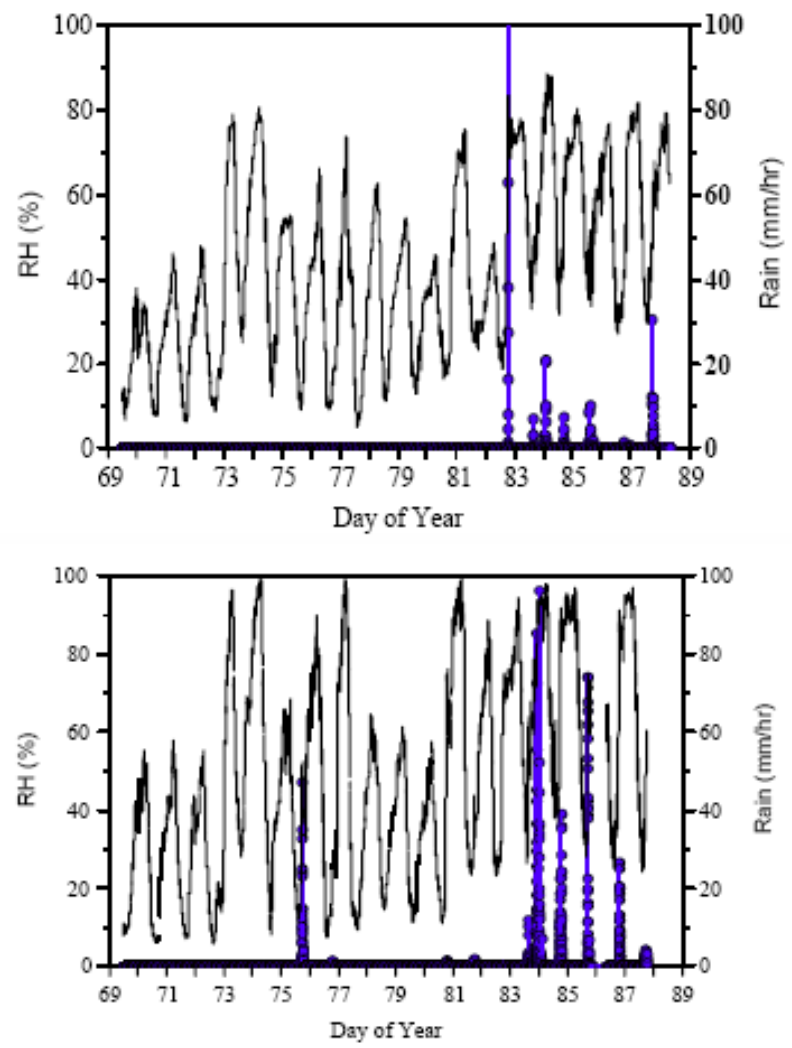

Fig. 1. Relative humidity and rain intensity (blue) measured at sites TO (top) and T1 (bottom) from 10 March (day 69) to 29 March (day 88) 2006 during the MILAGRO field campaign.

Relative humidity and rain intensity at site $\mathrm{T} 0$ during the study are shown in Fig. 1 (bottom). Rains events occurred at site $\mathrm{T} 1$ on 16, 17, 21, 22, and 24-28 March (days 75, 76, 80, $81,83-87$ ). Relative humidity ranged from a mid-day low of $40 \%$ during the first week to a high of $99 \%$ during the last week of March 2006. Winds ranged from 0.1 to $10 \mathrm{~m} / \mathrm{s}$ with an average of $2 \mathrm{~m} / \mathrm{s}$ from the south, southwest.

\section{Aerosol Optical Properties}

\subsubsection{Site T0}

The aerosol instrumentation at site T0 was located on the rooftop of Building No. 32 (Héctor Lara Sosa Building, IMP) $15 \mathrm{~m}$ above ground level. The sample inlets were designed to collect aerosols in the size range of 0.1 to 2 micron aerodynamic diameter (Hermann et al., 2001). Aerosol scattering was measured with a three wavelength integrating nephelometer (TSI Model 3563) operating at 450, 550, and $700 \mathrm{~nm}$ (Anderson and Ogren, 1998). Results obtained at $550 \mathrm{~nm}$ are reported here.
The instrument was calibrated by using $\mathrm{CO}_{2}$ according to the manufacturer's specifications. An internal high efficiency particulate filter (HEPA) is used to provide a clean air measurement periodically for background subtraction. The TSI nephelometer was operated at ambient relative humidity. However, two single wavelength $(550 \mathrm{~nm})$ nephelometers (Meteorology Research Incorporated) were operated at low (20\%) and high (80\%) relative humidity for comparison.

Aerosol absorption was measured with a multi-angle absorption photometer, or MAAP (Thermo Electron Model 5012). The aerosols in the air sample are collected within the instrument by continuous filtration through a glass fiber tape strip and the aerosol absorption is determined by measuring the attenuation of $670 \mathrm{~nm}$ light as it passes through the particle laden filter. As the sample is deposited on the filter tape, the light attenuation steadily increases. At high sample loadings the high absorption can cause detection limits to increase. To prevent this, the instrument automatically advances the tape to a new sample spot when light attenuation reaches $25 \%$ of its initial value. After the tape advance, a background measurement is taken to correct for variations in filter surfaces and source light intensities.

The use of the filter based aerosol absorption methods have been met with some controversy due to artifacts introduced by depositing the aerosol particles on a filter substrate prior to measurement (Schmid et al., 2005; Arnott et al., 2005). Since these instruments rely on the measurement of light transmitted through a particle laden quartz fiber filter, scattering from the filter surface causes a reduction in light intensity not associated with absorption, which results in a positive error in the attenuation measurement. The MAAP represents a significant improvement over other filter-based methods in that it uses multiple detectors to simultaneously measure the light intensity both transmitted through and scattered from the filter tape. The instrument then uses a two-streamapproximation radiative transfer scheme to determine the aerosol absorption. This explicit treatment of light scattering effects caused by the aerosol and filter matrix in the radiative transfer scheme improves the determination of aerosol absorption considerably over methods that rely on the measurement of transmission alone (Petzold et al., 2005).

The MAAP automatically calculates the $\mathrm{BC}$ content in the aerosol samples from the aerosol absorption measurements by assuming $\mathrm{BC}$ to be the main absorbing aerosol species in the samples with a mass specific absorption coefficient of $6.6 \mathrm{~m}^{2} / \mathrm{g}$ at $670 \mathrm{~nm}$. However, these results are easily reconverted to the initial aerosol absorption measurement using the manufacturer's absorption coefficient.

The aerosol absorption measurements obtained by the MAAP at $670 \mathrm{~nm}$ were corrected to $550 \mathrm{~nm}$ for direct comparison of the aerosol scattering measurements. The wavelength dependence of the extinction of light by fine aerosol particles $(\tau)$ is defined by Ångstrom's turbidity formula as $\tau=\beta \lambda^{-\alpha}$; where $\beta$, known as the Ångstrom turbidity coefficient, is the value of $\tau$ at a wavelength of $1 \mu \mathrm{m}$ and $\alpha$ is 
the Angstrom exponent. The total aerosol extinction is the sum of aerosol scattering and absorption as described in the expanded turbidity formula,

$\tau=\beta_{s} \lambda^{-\alpha s}+\beta_{a} \lambda^{-\alpha a}$

where $\alpha_{s}$ is the Ångstrom exponent for aerosol scattering, $\alpha_{a}$ is the Ångstrom exponent for aerosol absorption, and $\beta_{s}$ and $\beta_{a}$ are the corresponding values of aerosol scattering and absorption at a wavelength of $1 \mu \mathrm{m}$. The wavelength dependence of aerosol absorption can be determined independently by

$A=\beta \lambda^{-\alpha a}$ and

$\ln (A)=-\alpha_{a}^{*} \ln (\lambda)$

Once determined, $\alpha_{a}$ can then be used to convert absorption measurements made at one wavelength to values at another wavelength.

The aerosol absorption Ångstrom coefficients were calculated from Eq. (2) by using aerosol absorption measurements at 7 wavelengths $(370,450,520,590,660,880$, and $950 \mathrm{~nm}$ ) made with a 7-channel aethalometer (Hansen et al., 1982). The 7-channel aethalometer is currently the best method available for the determination of $\alpha_{a}$ in the field. The aethalometer is the only instrument available that allows for the measurement of aerosol absorption at more than 2 wavelengths and includes the UVB spectral range. It is important to include the UV measurement in the determination of $\alpha_{a}$ since most enhanced absorption occurs in this range (Bergstrom et al., 2002; Kirchstetter et al., 2004; Andreae and Gelencser, 2006; Barnard et al., 2008). Therefore, instruments that use only visible wavelengths to determine $\alpha_{a}$ will greatly underestimate the wavelength dependence of aerosol absorption.

For small spherical particles with a constant refractive index across the wavelength range of interest, $\alpha_{a}=1$ (Bergstrom, 1973). This has been determined to be a good approximation for aerosols composed mostly of $\mathrm{BC}$ or for particles containing a significant fraction of $\mathrm{OC}$ over a narrow wavelength range $<600 \mathrm{~nm}$ (Bergstrom et al., 2002; Kirchstetter et al., 2004). However, the aerosol absorption Ångstrom coefficients of mixed carbon aerosols containing $\mathrm{BC}$, secondary $\mathrm{OC}$, and primary $\mathrm{OC}$ from biomass burning has been found to be closer to 1.5 (Schmid et al. 2006). In areas impacted heavily by biomass burning, $\alpha_{a}$ can be closer to 2 to 2.5 (Dubovik et al., 1998; Kirchstetter et al., 2004; Swap et al., 2003). It is therefore important to determine $\alpha_{a}$ at the same time resolution as the absorption measurements to reduce errors in calculating aerosol absorption at different wavelengths. The aerosol absorption Ångstrom coefficients were calculated simultaneously with the aerosol absorption measurements obtained at $670 \mathrm{~nm}$ by the MAAP and these values were used to calculate aerosol absorption at $550 \mathrm{~nm}$. The results obtained for $\alpha_{a}$ at site T0 varied from 0.54 to 1.52 with an overall average of 0.93 (Marley et al., 2008).
The analog outputs of the MAAP absorption photometer and the nephelometers were monitored continuously and one-minute averages of aerosol absorption and scattering were recorded by a laptop computer operating with LabVIEW software. The data reported here are an hourly running average of the one-minute values for aerosol scattering at $550 \mathrm{~nm}$ and aerosol absorption corrected to $550 \mathrm{~nm}$ by Eq. (2).

The aerosol scattering measurements made at $550 \mathrm{~nm}$ and the aerosol absorption measurements corrected to $550 \mathrm{~nm}$ were used to calculate the fine mode aerosol single scattering albedo (SSA). The SSA is defined as the ratio of aerosol scattering to total light extinction (absorption + scattering) as

$\mathrm{SSA}=\sigma_{s} /\left(\sigma_{s}+\sigma_{a}\right)$

where $\sigma_{s}$ is the aerosol scattering coefficient and $\sigma_{a}$ is aerosol absorption coefficient. The SSA is therefore the fraction of total light extinction that is due to scattering by aerosols. The results reported here for aerosol SSAs are for the fine mode aerosols only. These are expected to be lower than that for the total aerosol burden due to the fact that the highly absorbing carbonaceous aerosols exist principally in the fine mode. However, the more highly scattering coarse mode aerosols in the size range of 2-10 micron aerodynamic diameter have settling velocities from $60-1000 \mathrm{~cm} / \mathrm{h}$ and will not be transported as far into the surrounding region unless they are accompanied by high winds and/or are lofted to significant altitude (Finlayson-Pitts and Pitts, 2000).

\subsubsection{Site T1}

The sample inlet at site T1was located at a height of $10 \mathrm{~m}$ above ground level and collected aerosols in the size range of 0.1 to 2 micron aerodynamic diameter at a flow rate of $16.71 / \mathrm{min}$ at ambient temperature and pressure. Aerosol scattering was measured at site $\mathrm{T} 1$ with a portable integrating nephelometer (Radiance Research Model 903) operating at $530 \mathrm{~nm}$, which was calibrated by comparison to a second nephelometer (Radiance Research Model 903) located at the Universidad Nacional Autónoma de México (UNAM). The scattering measurements were recorded by internal data loggers at $1 \mathrm{~min}$ intervals. The stored data was retrieved using a personal computer through an RS232 port. These data are reported here as an hourly running average of these one minute values.

Aerosol absorption was obtained by a particle soot absorption photometer, or PSAP (Radiance Research), which is also a filter based measurement technique. The particle laden air stream is first passed through a primary filter and the aerosol absorption is determined by measuring the light attenuation at $550 \mathrm{~nm}$. The clean air stream is then passed through a second filter adjacent to the primary filter, which is used as a reference in order to ensure that the observed change in primary filter transmittance is not due to changes in the intensity of the light source. 

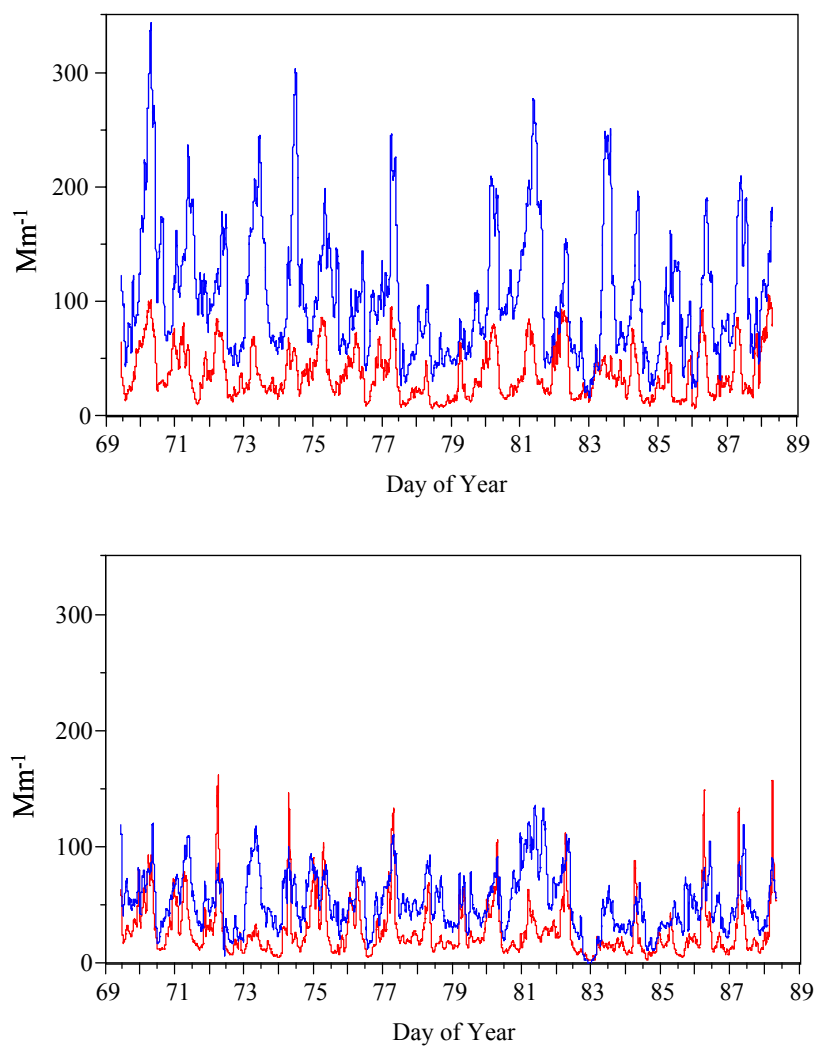

Fig. 2. Measurements of fine (0.1-2 micron) aerosol absorption (red) and scattering (blue) obtained at sites T0 (top) and T1 (bottom) from 10 March (day 69) to 29 March (day 88) 2006 during the MILAGRO field campaign.

The PSAP is also susceptible to errors associated with measuring light transmission through a particle laden filter substrate. Light scattering from the filter surface as well as multiple scattering within the filter medium results in an enhancement of the absorption measurements (Arnott et al., 2005). The instrument manufacturer has empirically determined calibration factors to correct for both the magnification of the absorption by the filter medium as well as for nonlinearities in the instrument response as the filter is loaded with particulates. The aerosol absorbances $\left(\sigma_{a}\right)$ reported here for $550 \mathrm{~nm}$ were calculated from the measured aerosol absorbances $\left(\sigma_{\text {meas }}\right)$ by Eq. $(5)$;

$\sigma_{a}=\left(\sigma_{\text {meas }}-\mathrm{K}_{1} \sigma_{s}\right) / \mathrm{K}_{2}$

where $\sigma_{s}$ is the measured aerosol scattering, $\mathrm{K}_{1}=0.02$, and $\mathrm{K}_{2}=1.2$ (Bond et al., 1999). In addition, transmittance values below 0.5 have been omitted as invalid due to low particle loadings on the filter.

\subsection{Meteorology and UV-B measurements}

Broadband ultraviolet-B (UV-B) radiation measurements were taken at both site $\mathrm{T} 0$ and site $\mathrm{T} 1$ with RobertsonBerger (RB) radiometers (Solar Light Co. Model 501). These radiometers record continuous measurement of global (direct + diffuse) broadband ultraviolet radiation from 280-320 nm. Since the output of the detectors vary $1 \%$ per degree $\mathrm{C}$, the internal temperatures of the radiometers are maintained at $25 \pm 1^{\circ} \mathrm{C}$ with Peltier elements inside the housings and the internal temperature is monitored to assure stability. Both radiometers were factory calibrated with a $200 \mathrm{~W}$ quartz halogen lamp traceable to NIST. After calibration, stability of the detectors has been shown to be excellent over the life of the meter (Deluisi et al., 1992; Weatherhead et al., 1997; Xu and Huang, 2003). The detector has a spectral response that mirrors the erythemal action spectra (McKinlay and Diffy, 1987). They are calibrated in units of minimum erythemal dose per hour $(\mathrm{MED} / \mathrm{h})$ where one $\mathrm{MED} / \mathrm{h}$ is defined as $0.0583 \mathrm{~W} / \mathrm{m}^{2}$. Results reported here have been converted to $\mu \mathrm{W} / \mathrm{cm}^{2}$.

Measurements of wind speed, wind direction, rain intensity, pressure, temperature, and relative humidity $(\mathrm{RH})$ were obtained at both sites with weather multi-sensor packages (Vaisala, WXT150). Rain intensity measurements reported here were made by the RAINCAP sensor included in the weather package. The sensor detects the impact of individual raindrops by a piezoelectric sensor. The resulting voltage signal is proportional to the volume of the drop and is converted into total accumulated precipitation. All measurements were collected at a five-minute time resolution with a laptop computer operating with LabVIEW software.

\subsection{Total Carbon Determinations}

Samples of fine $(<1.0$ micron) aerosols were collected in Mexico City from 1-28 March 2006 (day 60-day 68) at site T0 and site T1. The Aerosol samples were collected on quartz fiber filters by using high volume samplers (Hi-Q Environmental. Products, Model HVP-3800AFC) equipped with cascade impactors (Thermo Anderson). The air samplers were equipped with brushless, three stage centrifugal fan blowers controlled by an electronic mass flow sensor that detects changes in pre-set flow rate caused by changes in temperature, barometric pressure, and pressure drop due to particulate loading on filter media. The high-volume sampler compensates for these changes by adjusting the motor speed to maintain the pre-set flow rate at $1.1 \mathrm{cubic} \mathrm{m} / \mathrm{min}$ or $40 \mathrm{scfm}$. Three separate LCD's, display elapsed time, total volume of air sampled, and instantaneous flow rate.

The quartz filter samples were taken at 12-h intervals from 05:30 to $17: 30$ and from 17:30 to $05: 30$ local standard time (LST). The volume of air sampled during the 12-h time period averaged $740 \mathrm{~m}^{3}$. The aerosol samples were analyzed for TC content by thermal combustion. Each sample was 
sealed under vacuum in a quartz tube with copper oxide, metallic copper and silver and combusted at $900^{\circ} \mathrm{C}$. The $\mathrm{CO}_{2}$ produced from combustion was cryogenically isolated from other combustion products and its amount measured manometrically $( \pm 0.2 \%)$.

\section{Results and discussion}

The results of fine aerosol absorption and scattering at sites $\mathrm{T} 0$ and $\mathrm{T} 1$ are shown in Fig. 2. Aerosol absorption at site T0 ranged from $7-107 \mathrm{Mm}^{-1}$ with an overall average of $37 \mathrm{Mm}^{-1}$ and followed a diurnal pattern that reached a maximum at around 06:30 (range of 05:00 to 08:00) LST and a minimum at 13:00 (range of 12:00 to 14:00) LST. Previous measurements of aerosol absorption have been reported for the Centro de Ciencias de la Atmósphera inside the campus of UNAM in the southwest quadrant of the Mexico City basin (Baumgardner et al., 2007). Results averaged over 14 days between the years 2003 and 2005 were found to follow a similar diurnal pattern as observed at site $\mathrm{T} 0$ but results were much lower than reported here. Aerosol absorption ranged from a low of $7 \mathrm{Mm}^{-1}$ in the early morning (01:00) to a maximum of $33 \mathrm{Mm}^{-1}$ at 06:00 LST. A comparison of the aerosol absorption at T0 showed excellent agreement with data obtained from co-located aethalometer and photoacoustic spectrometer instrumentation (Paredes-Miranda et al., 2008).

The values obtained in this study can also be compared to aerosol absorption measurements reported for Santiago, Chile, which has a similar terrain but a lower altitude. The major sources of absorbing aerosols in both Mexico City and Santiago are motor vehicle traffic, especially diesel buses (Horvath et al., 1997; Molina and Molina, 2002). Aerosol absorption in Santiago was found to reach maximum values of $100-200 \mathrm{Mm}^{-1}$ at around 09:00 LST and correlated with peak traffic hours (Horvath et al., 1997).

Aerosol absorption measurements at site $\mathrm{T} 1$ ranged from 3-147 $\mathrm{Mm}^{-1}$ with an overall average of $27 \mathrm{Mm}^{-1}$. The same diurnal pattern observed at T0 was also evident at site T1 (maximum at 06:30 and minimum at 13:00 LST). While the daily maximum absorption values at $\mathrm{T} 1$ exceeded those at T0 on 9 of the days studied, these high levels were of much shorter duration, lasting only about 1 to $2 \mathrm{~h}$ as compared to 7 to $9 \mathrm{~h}$ of peak levels at site T0. In addition, the minimum aerosol absorption observed at site $\mathrm{T} 1$ routinely fell below those observed at site $\mathrm{T} 0$.

Forty-six minute averages of aerosol absorption obtained from day 74 (15 March) through day 85 (26 March) with a photoacoustic spectrometer operating at $870 \mathrm{~nm}$ have been reported previously for site T1 (Doran et al., 2007). A comparison of the daily absorbance maxima reported at $870 \mathrm{~nm}$ (Doran et al., 2007) with those recorded by the PSAP at $550 \mathrm{~nm}$, assuming an $\alpha_{a}$ of 1 , yields a difference between the data sets of -0.1 to $+83 \mathrm{Mm}^{-1}$ with an average difference of
$31 \mathrm{Mm}^{-1}$. The major source of error in this comparison is probably due to the assumption of $\alpha_{a}=1$. During much of the MILAGRO study, site T1 was impacted by local grass fires (Gaffney et al., 2008; Yokelson et al., 2008), which could have contributed significantly to the overall aerosol loadings and to a larger $\alpha_{a}$ (Kirchstetter et al., 2004). Carbon-14 analysis of 12-h aerosol samples collected at site $\mathrm{T} 1$ found that $70 \%$ of the carbon in the aerosols was from modern sources (Gaffney et al., 2008), which confirms that much of the carbon aerosol burden in the area arises from biomass derived sources. Determinations of $\alpha_{a}$ in areas impacted by biomass burning have been shown to be closer to 2 (Dubovik et al., 1998; Kirchstetter et al., 2004; Swap et al., 2003). If $\alpha_{a}=2$ is used to convert the values reported at $870 \mathrm{~nm}$ to $550 \mathrm{~nm}$, the difference in the two data sets becomes $1 \mathrm{Mm}^{-1} \pm 30 \mathrm{Mm}^{-1}$. The major source of error in this comparison is most likely due to the differences used in data averaging.

Aerosol scattering measurements obtained at site T0 ranged from $16-344 \mathrm{Mm}^{-1}$ with an overall average of $105 \mathrm{Mm}^{-1}$. Scattering values generally reached a maximum at 10:30 (range of 07:30 to 13:00) LST. Measurements of aerosol scattering species obtained in Mexico City in April 2003 found that both nitrate and ammonium concentrations showed a sharp diurnal pattern with a maximum of 10 $20 \mu \mathrm{g} / \mathrm{m}^{3}$ for nitrate and $4-8 \mu \mathrm{g} / \mathrm{m}^{3}$ for ammonium occurring from 10:00-12:00 LST, while sulfate concentrations did not vary significantly, remaining at round $2-3 \mu \mathrm{g} / \mathrm{m}^{3}$ most of the time (Salcedo et al., 2006). The sharp diurnal pattern of nitrate is due to the photochemical formation of nitric acid from the reaction of $\mathrm{NO}_{2}$ and $\mathrm{OH}$, and subsequent reaction with ammonia to form the highly scattering aerosol species ammonium nitrate.

Similar rapid photochemical production of secondary organic aerosols (SOA) has also been observed in the Mexico City area (Salcedo et al., 2006; Hennigan et al., 2008; Aiken et al., 2008; Volkamer et al., 2006). The formation of particulate nitrate and SOA were found to be highly correlated suggesting that reaction with $\mathrm{OH}$ was also the primary source of the morning rise in SOA (Salcedo et al., 2006; Hennigan et al., 2008). The photochemical SOA formation showed approximately the same enhancement as for ammonium nitrate and occurred between the hours of 08:00-12:45 (Hennigan et al., 2008; Salcedo et al., 2006). This late morning formation of both ammonium nitrate and SOA in Mexico City contributes to the aerosol scattering in the diurnal profile shown in Fig. 2.

Aerosol scattering measured in Denver during the winter reached a maximum of $60-140 \mathrm{Mm}^{-1}$ at approximately 14:00-19:00 LST, 6h later than observed in Mexico City (Groblicki et al., 1981). The primary aerosol scattering species in Denver is ammonium sulfate formed from the atmospheric oxidation of $\mathrm{SO}_{2}$, with significant contributions from ammonium nitrate, as well. The photochemical formation of these secondary aerosol species would be expected to be slower in Denver due to the lower actinic flux in the winter 

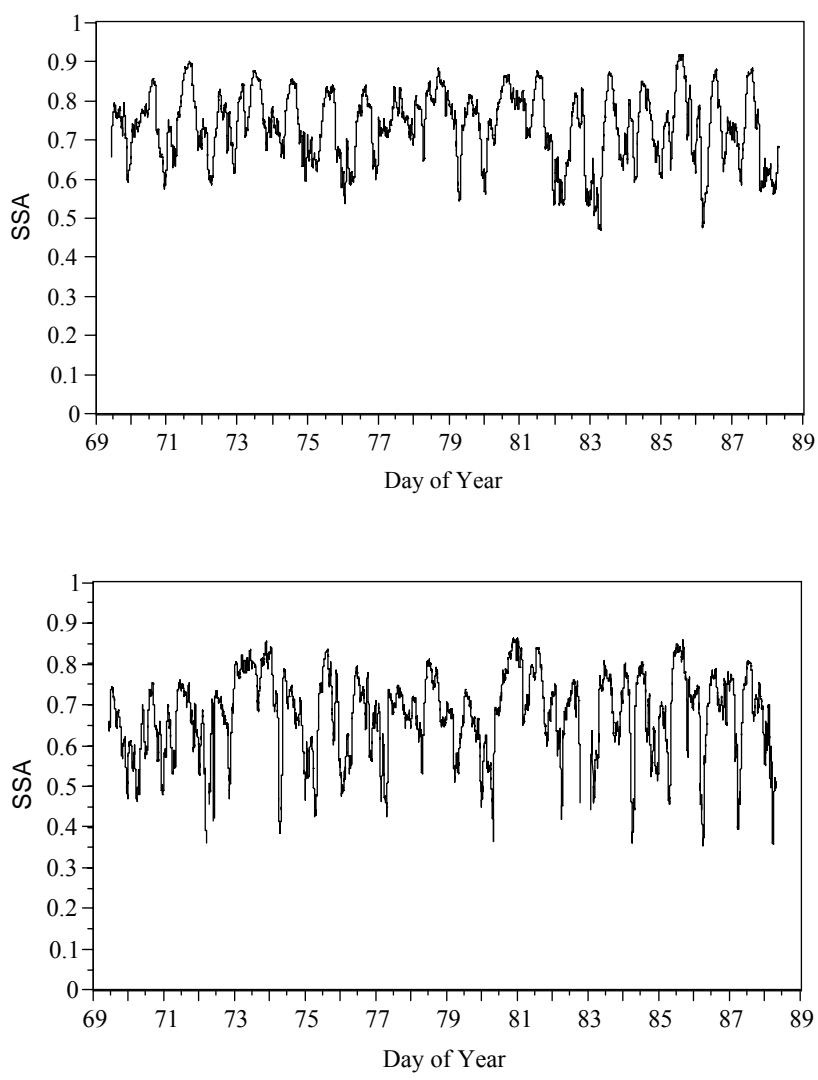

Fig. 3. Aerosol single scattering albedo (SSA) determined at site T0 (top) and T1 (bottom) from 10 March (day 69) to 29 March (day 88) 2006 during the MILAGRO field campaign.

at these higher latitudes, resulting in the later scattering maxima than observed in Mexico City. Aerosol scattering values at $\mathrm{T} 1$ were in general much lower than at T0, ranging from 2 $136 \mathrm{Mm}^{-1}$ with an overall average of $53 \mathrm{Mm}^{-1}$, and reached a maximum at 08:30 (range of 06:00 to 13:30) LST. On clear days the boundary layer in Mexico City during March-April grows slowly after sunrise at 06:40 to a height of approximately $1000 \mathrm{~m}$ by 11:00 LST (Doran et al., 1998, 2007; de Foy et al., 2008; Fast and Zhong, 1998; Fast et al., 2007). This serves to dilute the pollutants already present in the boundary layer. After 12:00 LST the boundary layer grows rapidly to $3000 \mathrm{~m}$ or greater. The maximum scattering values at site T0 occurred $2 \mathrm{~h}$ later than the maximum scattering values seen at $\mathrm{T} 1$ and $4 \mathrm{~h}$ later than the peak aerosol absorption values. This suggests that the high aerosol scattering values measured at $\mathrm{T} 0$ were primarily due to rapid SOA formation in the city. Although the overall SOA levels at T1 were found to be similar to those at T0 (Hennigan et al., 2008; Stone et al., 2008), the diurnal pattern of aerosol scattering at site T1 appeared to be controlled primarily by changes in the boundary layer height in the early morning, and by the presence of photochemically aged aerosols in the afternoon (Carabalì, 2008; Stone et al., 2008; Aiken, et al., 2008).
The fine mode aerosol SSAs calculated from the ground level absorption and scattering measurements at $550 \mathrm{~nm}$ are shown in Fig. 3. The lower aerosol scattering observed at site T1 translates into lower values for fine aerosol SSAs at T1 with a range of $0.35-0.86$ and an overall average of 0.68 . The very low values for SSAs at site $\mathrm{T} 1$ are of very short duration, indicating a local source of absorbing $\mathrm{BC}$ aerosol. The fine aerosol SSAs calculated for site T0 ranged from 0.470.92 with an overall average of 0.73 . While the total aerosol SSAs recorded over most of the Northern Hemisphere are usually about $0.85-0.95$ (Jacobson, 2001), values as low as 0.68 have been reported over the southern Atlantic Ocean (Clarke, 1989). The occurrence of lower total aerosol SSAs is an indication of higher levels of more absorbing fine mode aerosols.

The SSA is a function of aerosol chemical composition and morphology. For a completely scattering aerosol, such as sulfate, the SSA $\sim 1$ and for a highly absorbing aerosol, such as freshly emitted BC, the SSA theoretically would approach zero. The SSA of freshly emitted diesel soot has been reported at 0.2 (Ramanathan et al., 2001; Ban-Weiss et al., 2008). Therefore, aerosols with an SSA $>0.95$ will have a negative climate forcing and an overall cooling effect on the atmosphere, while an SSA $<0.85$ will result in a positive climate forcing and an overall warming effect due to the enhanced aerosol absorption (Ramanathan et al., 2001). In addition, the presence of highly absorbing fine mode aerosols in the lower atmosphere will result in heating of the particles and significant local warming of the boundary layer (Hermann and Hanel, 1997; Ramanathan and Carmichael, 2008). This can result in an increase in the convective available potential energy of the boundary layer and a large scale rising motion over time (Chung and Zhang, 2004). This may help to explain the rapid increase in the boundary layer height observed in this area (Shaw et al., 2008; Fast and Zhong, 1998; Whiteman et al., 2000).

Doran et al. (2007) have calculated forward and back trajectories of air masses at $1000 \mathrm{~m}$ above ground level (a.g.l.) over site T1 during daylight hours (06:00-18:00 LST) for a 20-day period during the month of March 2006. The most favorable conditions for transport from site $\mathrm{T} 0$ to site $\mathrm{T} 1$ were seen to occur on days $69,70,77,78,79,81,83,86$ and 87 (10-11, 18-20, 22, 24, 27-28 March). On days 71-76 (12-17 March) and day 82 (23 March) the back trajectories indicate that transport would have likely been from site $\mathrm{T} 1$ towards Mexico City and site T0.

The aerosol absorption, scattering, and SSAs obtained at site T0 and $\mathrm{T} 1$ have been averaged over the same daylight hours reported by Doran et al. (2007) for direct comparison to their calculated back trajectories. The daily average aerosol absorption at sites $\mathrm{T} 0$ and $\mathrm{T} 1$ is shown in Fig. 4 along with the measurement ranges observed during each day. The daily average absorption values are similar at both sites ranging from $16-50 \mathrm{Mm}^{-1}$ with an overall average value of $35 \mathrm{Mm}^{-1}$ at $\mathrm{T} 0$ and a range of $15-41 \mathrm{Mm}^{-1}$ 

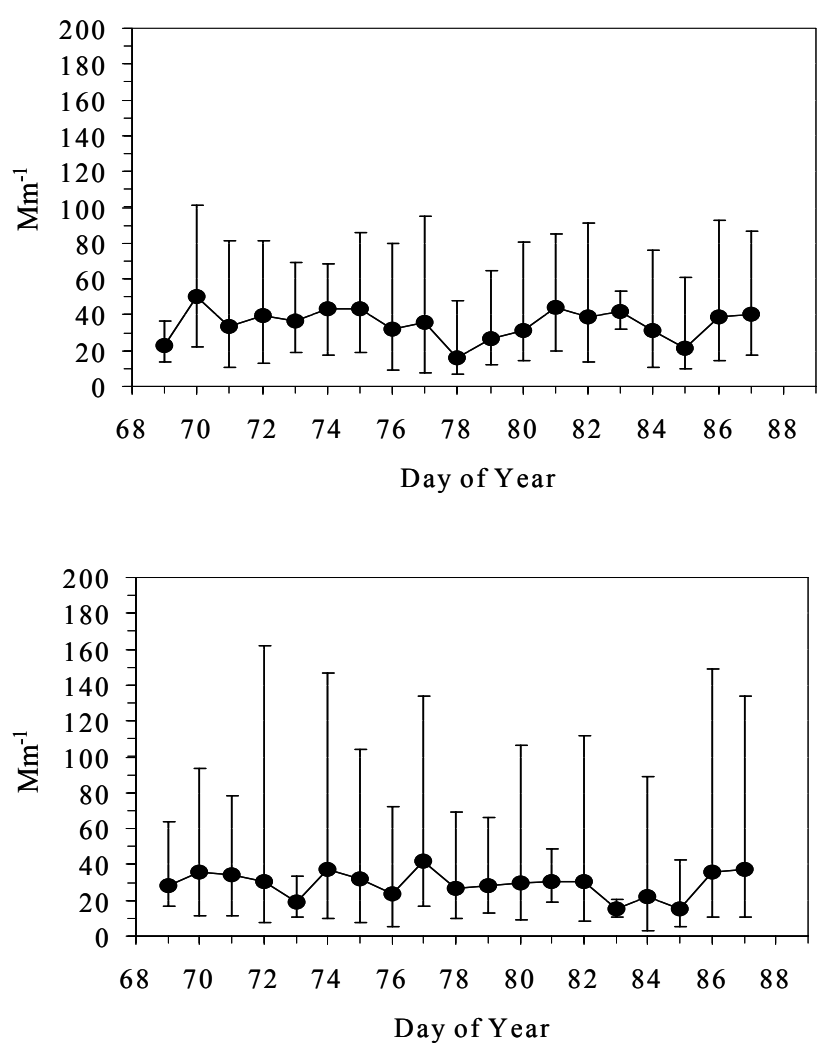

Fig. 4. Daily aerosol absorption averaged from 06:00 18:00 LST and absorption ranges measured at sites T0 (top) and T1 (bottom) from 10 March (day 69) to 29 March (day 88) 2006 during the MILAGRO field campaign.

with an overall average of $29 \mathrm{Mm}^{-1}$ at site $\mathrm{T} 1$. The two sites differ primarily in the range of aerosol absorption values observed during the day. While the lower limits on the ranges are similar at both sites, indicating a regional background of around $5 \mathrm{Mm}^{-1}$, the upper limits of the aerosol absorption measurements are more variable at site $\mathrm{T} 1$ with a range of 21-162 $\mathrm{Mm}^{-1}$ as compared to site T0 with a range of 36$101 \mathrm{Mm}^{-1}$. There also appears to be no clear correlation of absorption values with transport from the Mexico City area, again indicating a local source of absorbing aerosols at site T1. Days 77, 86 and 87 (18, 27, 28 March), which were identified as likely transport days from site T0 to site T1, show high maximum aerosol absorbance. However, high maxima were also observed on days 72 and 74 (13 and 14 March) when transport has been identified as from the north. This suggests an impact at site T1 from Pachuca and/or Tizayuca (an important industrial center), which are located 10 and $64 \mathrm{~km}$ northeast of T1. Concentrations of TC obtained on fine mode aerosol samples collected over the daylight hours at sites T0 and T1 are shown in Fig. 5. The overall profile of the daily carbon concentrations during the study period is similar at both sites with the highest values $\left(25-35 \mu \mathrm{g} / \mathrm{m}^{3}\right)$

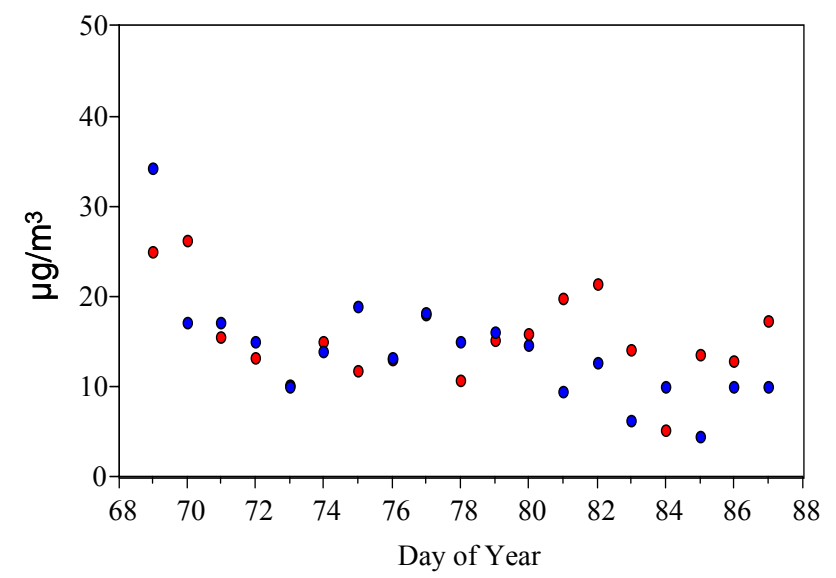

Fig. 5. Total carbon concentrations measured on fine (0.1-1 micron) aerosol samples collected from 05:30-17:30 at site T0 (red) and T1 (blue) from 10 March (day 69) to 29 March (day 88) 2006 during the MILAGRO field campaign.

observed on the first two days of the study period and lower values $\left(5-15 \mu \mathrm{g} / \mathrm{m}^{3}\right)$ during the rest of the study. The mass absorption coefficients for BC at $550 \mathrm{~nm}$ were estimated assuming that the $\mathrm{TC}$ content of the $<1$ micron aerosols was $30 \% \mathrm{BC}$. This is in good agreement with past measurements made in the Mexico City area (Chow et al., 2002; Vega et al., 2004) as well as for measurements made in other urban areas (Tanner et al., 1982; Gaffney et al., 1984). The adjusted values reported for $\mathrm{OC} / \mathrm{EC}$ ratios measured at site $\mathrm{T} 1$ are also in this range (Doran, 2007) as well as estimates made from aerosol mass spectrometry measurements (Aiken et al., 2008; Salcedo et al., 2006). The BC mass absorption coefficients shown in Fig. 6 range from 3.0-12.2 $\mathrm{m}^{2} / \mathrm{g}$ with an average of $7.7 \mathrm{~m}^{2} / \mathrm{g}$ at T0 and from $2.7-12.3 \mathrm{~m}^{2} / \mathrm{g}$ with an average of $7.7 \mathrm{~m}^{2} / \mathrm{g}$ at $\mathrm{T} 1$.

The mass absorption for $\mathrm{EC}$ reported for $\mathrm{T} 1$ by continuous OC/EC analysis was $5.6 \mathrm{~m}^{2} / \mathrm{g}$ with a range of $1-18 \mathrm{~m}^{2} / \mathrm{g}$ at $870 \mathrm{~nm}$ and $8.9 \mathrm{~m}^{2} / \mathrm{g}$ at $550 \mathrm{~nm}$ assuming an $\alpha_{a}$ of 1 (Doran, 2007). Other reported estimates of BC mass absorption in Mexico City vary from $4.8 \mathrm{~m}^{2} / \mathrm{g}$ (Baumgardner et al., 2007) to $9.5 \mathrm{~m}^{2} / \mathrm{g}$ (Schuster et al., 2005) at $550 \mathrm{~nm}$. The mass absorption coefficient for BC calculated from a multi-filter rotating shadow-band radiometer (MFRSR) measurements in Mexico City was reported to be $8.2-8.9 \mathrm{~m}^{2} / \mathrm{g}$ at $550 \mathrm{~nm}$ as (Barnard et al., 2007, 2008). However, these estimations are based on assumptions of $\mathrm{BC}$ density, BC refractive index, and aerosol mixing state and may have a "worst case" uncertainty of about 70\% (Barnard et al., 2008).

While the mass absorption coefficient of freshly emitted $\mathrm{BC}$ aerosols is estimated to be in the range of 6.3$8.7 \mathrm{~m}^{2} / \mathrm{g}$ at $550 \mathrm{~nm}$ (Bond and Bergstrom, 2006), OC aerosol species such as humic-like substances (HULIS) derived from biomass burning or secondary organic aerosols generated photochemically have mass absorption coefficients $<1 \mathrm{~m}^{2} / \mathrm{g}$ 


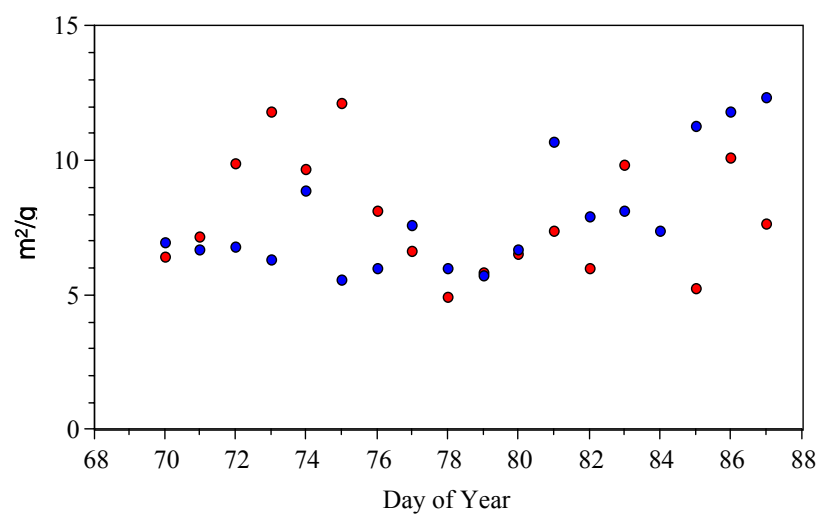

Fig. 6. Daily average mass absorption coefficient calculated for black carbon at site T0 (red) and T1 (blue) from 10 March (day 69) to 29 March (day 88) 2006 during the MILAGRO field campaign.

at $550 \mathrm{~nm}$ (Hoffer et al., 2006; Patterson and McMahon, 1984). The overall mass absorption coefficients measured for total carbon $(\mathrm{BC}+\mathrm{OC})$ will be dependent on the relative concentrations of $\mathrm{BC}$ and $\mathrm{OC}$ as well as their mixing state (Hitzenberger and Pauxbaum, 1993; Bond et al., 2006). The similarity of the mass absorption for both sites T0 and T1 suggests that the aerosol carbon composition was similar at both sites. The fine mode aerosol scattering averaged over the daylight hours is shown in Fig. 7 for sites T0 and T1 along with the measurement ranges for each day. The daily averages vary from $60-187 \mathrm{Mm}^{-1}$ with an overall average of $123 \mathrm{Mm}^{-1}$ at T0. The daily average aerosol scattering was lower and more consistent at site $\mathrm{T} 1$ with a range of $38-105 \mathrm{Mm}^{-1}$ and an overall average of $57 \mathrm{Mm}^{-1}$. There also does not seem to be a general trend of major impacts on aerosol scattering at T1 due to transport from Mexico City except for possibly day 81 (22 March). Day 81 was identified as having favorable conditions for transport from site T0 to site T1 (Doran et al., 2007) and that day showed high scattering values for both sites.

The period from day 82 (23 March) to day 87 (24 March) was dominated by heavy regional rains and an overall increase in relative humidity (see Fig. 1). Rain totals before day 82 were $0 \mathrm{~mm}$ at site $\mathrm{T} 0$ and $6.7 \mathrm{~mm}$ at site T1. After day 82 rain totals were $19.2 \mathrm{~mm}$ at T0 and $59.5 \mathrm{~mm}$ at T1. This was accompanied by an increase in the average daily maximum RH from $59 \%$ to $76 \%$ at T0 and from $73 \%$ to $89 \%$ at $\mathrm{T} 1$. The increased rains resulted in a decrease in aerosol scattering at both sites by approximately the same amount. The average aerosol scattering at site T0 before the rainy period was $128 \mathrm{Mm}^{-1}$ (range of $62-197 \mathrm{Mm}^{-1}$ ) and during the rainy period the aerosol scattering dropped to $118 \mathrm{Mm}^{-1}$ (range of $85-157 \mathrm{Mm}^{-1}$ ). The same values for site T1 were $61 \mathrm{Mm}^{-1}$ (range of $39-105 \mathrm{Mm}^{-1}$ ) before day 82 and $50 \mathrm{Mm}^{-1}$ (range of $38-66 \mathrm{Mm}^{-1}$ ) after day 82 . However, the aerosol absorption remained the same at site
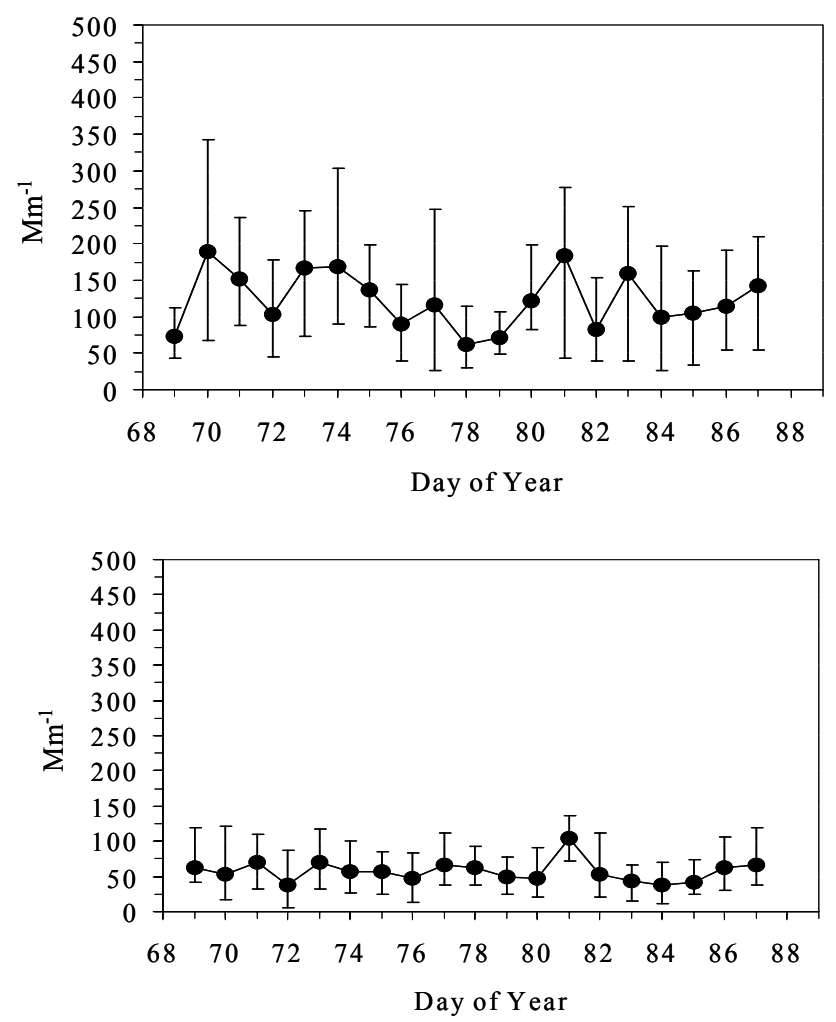

Fig. 7. Daily aerosol scattering averaged from 06:00-18:00 LST and scattering ranges measured at sites T0 (top) and T1 (bottom) from 10 March (day 69) to 29 March (day 88) 2006 during the MILAGRO field campaign.

T0 with a value before day 82 of $35 \mathrm{Mm}^{-1}$ (range of 16$50 \mathrm{Mm}^{-1}$ ) and a value of $35 \mathrm{Mm}^{-1}$ (range of $21-42 \mathrm{Mm}^{-1}$ ) after day 82 . The aerosol absorption at $\mathrm{T} 1$ decreased slightly from $30 \mathrm{Mm}^{-1}$ (range of $19-41 \mathrm{Mm}^{-1}$ ) before the rainy period to $26 \mathrm{Mm}^{-1}$ (range of $15-37 \mathrm{Mm}^{-1}$ ) during the rainy period. Since a significant fraction of highly scattering nonabsorbing aerosols are primarily inorganic and hydrophilic, it is expected that they will wash out more readily during rain events than the freshly emitted absorbing $\mathrm{BC}$ aerosols that are more hydrophobic in nature (Marley et al., 2000; Gaffney and Marley, 2005; Marley and Gaffney, 2007). However, as the $\mathrm{BC}$ aerosols become coated with SOA, they will become more hydrophilic in nature and their washout rates would be expected to increase.

The fine mode aerosol SSAs averaged over the daylight hours at site $\mathrm{T} 0$ and $\mathrm{T} 1$ are shown in Fig. 8. The average fine aerosol SSA at site T0 ranged from $0.72-0.83$ with an overall average of 0.78 while the average fine aerosol SSA at T1 was slightly lower and ranged from $0.63-0.78$ with an overall average of 0.70 . Doran et al. (2007) reported daily average total column aerosol SSAs at T1 at $500 \mathrm{~nm}$ determined by using a MFRSR. These results were reported for days 71, 78 and 86 as $0.84,0.85$ and $0.89(12,19$, and 27 March) (Doran et 

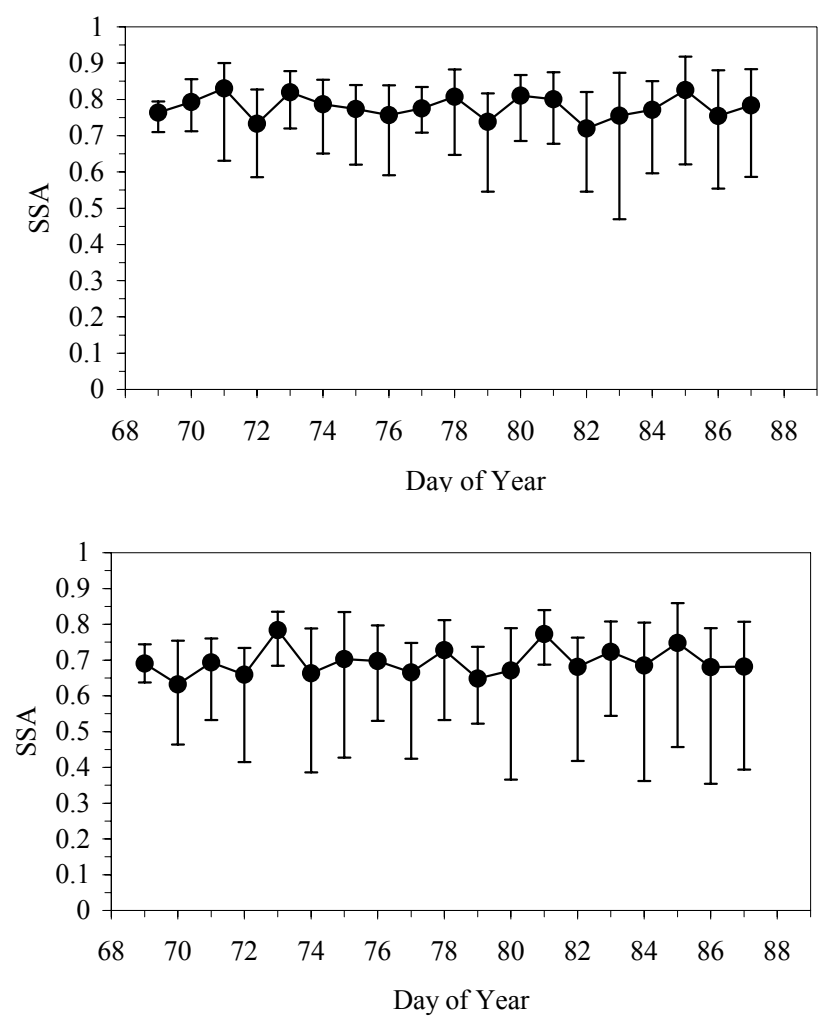

Fig. 8. Daily aerosol single scattering albedo (SSA) averaged from 06:00-18:00 LST and SSA ranges measured at sites T0 (top) and T1 (bottom) from 10 March (day 69) to 29 March (day 88) 2006 during the MILAGRO field campaign.

al., 2007). The corresponding average fine aerosol SSAs reported here from ground-based aerosol absorbance and scattering measurements at 550 are $0.69,0.73$, and 0.68 . The MFRSR SSA values are for the total aerosol burden while the values calculated in this work represent a surface measurement of fine mode aerosols only. The fine aerosol fraction measured here ( 0.1 to 2 micron diameter) contains the more highly absorbing carbonaceous aerosols. The much larger mechanically generated coarse mode aerosols ( $>2$ micron), which are included in the MFRSR measurements are very highly scattering species. The total aerosol SSAs are therefore generally expected to be higher than the SSAs measured for the fine aerosol fraction alone.

Daily average fine mode aerosol SSAs have also been reported for La Merced, located in central Mexico City, and Pedregal, a suburban neighborhood in the southwest portion of Mexico City during March of 1997 (Eidels-Dubovoi, 2002). These SSA values were calculated from ground level aerosol absorption measurements obtained with a single channel aethalometer and aerosol scattering measurements obtained by an open air integrating nephelometer at $530 \mathrm{~nm}$. The SSA values reported at La Merced varied from $0.63-0.86$ with an
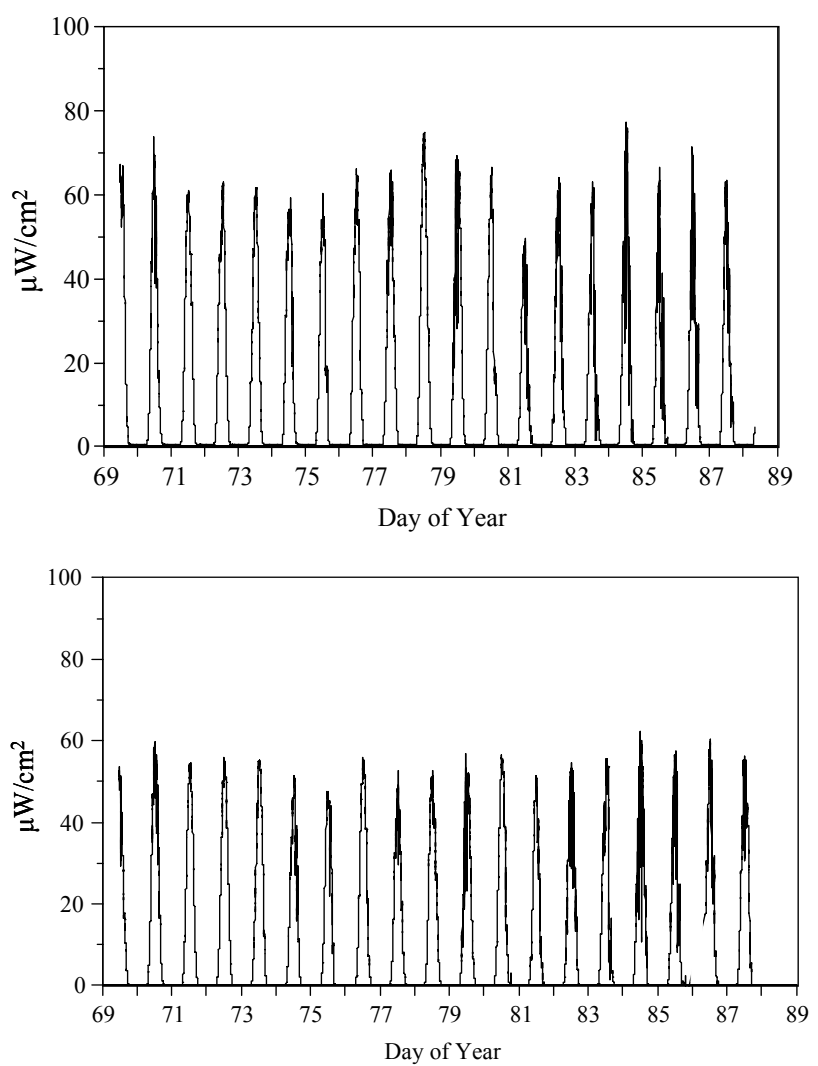

Fig. 9. Broadband UVB measured at sites T0 (top) and T1 (bottom) from 10 March (day 69) to 29 March (day 88) 2006 during the MILAGRO field campaign.

average of 0.72 and those reported at Pedregal ranged from $0.60-0.84$ with an average of 0.68 . These results compare well with the fine mode aerosol SSAs reported here.

Broadband UVB measurements obtained at sites T0 and $\mathrm{T} 1$ are shown in Fig. 9. The UVB intensity was higher at site T0, with an average of $64 \mu \mathrm{W} / \mathrm{cm}^{2}$ and a range of 50$70 \mu \mathrm{W} / \mathrm{cm}^{2}$ at solar noon, than at site $\mathrm{T} 1$, which had an average of $54 \mu \mathrm{W} / \mathrm{cm}^{2}$ and a range of $48-58 \mu \mathrm{W} / \mathrm{cm}^{2}$ at solar noon. In general, UVB reached a maximum at both sites at 12:30 LST. However, the variability of the daily maximum was larger at site T0 (11:30-14:00 LST) than at site T1 (12:00-13:00 LST). A comparison of simultaneous measurements from site $\mathrm{T} 0$ and $\mathrm{T} 1$ for cloudless days gave a correlation coefficient of 0.931 (slope of 1.18, intercept of 1.01). The measured UVB irradiances have been compared to that expected for clear sky conditions as determined by a radiative transfer model developed at The University of Chicago (Frederick and Lubin, 1988). The input to this model includes column ozone, determined from the Total Ozone Mapping Spectrometer (TOMS) satellite data, atmospheric optical thickness, UVB surface albedo, site location, day of year and time of day. The results of this comparison 


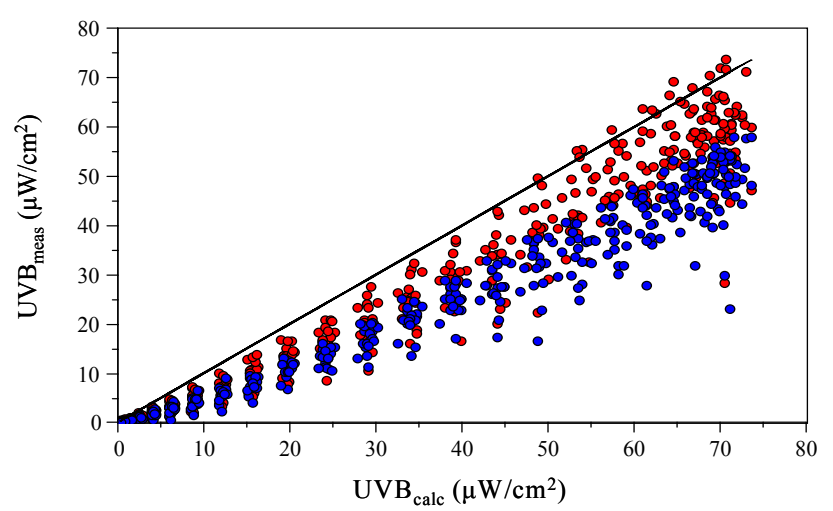

Fig. 10. Broadband UVB measured at sites T0 (red) and T1 (blue) compared to calculated clear sky UVB on days without rain events during the MILAGRO field campaign.

are shown in Fig. 10 for days without rain events. Both sites show reduced UVB radiation when compared to the clear sky modeled values, as expected for sites with significant UVB absorbing gases and aerosols (Castro et al., 2001; Gaffney et al., 2002; Barnard et al., 2008). However, the UVB radiation field observed at site $\mathrm{T} 1$ is reduced further than that observed at site T0. The measured UVB at both sites showed good correlation with the modeled UVB values $\left(r^{2}=0.95,0.96\right)$. However, the slope for site $\mathrm{T} 0$ was 0.87 while that for site $\mathrm{T} 1$ was 0.72 . It should be noted that ozone, an important UVB absorbing gas was at similar or higher levels at $\mathrm{T} 0$ than $\mathrm{T} 1$, and the difference in observed UVB at the sites was not due to higher ozone at $\mathrm{T} 1$ for the clear days examined.

The ratio of UVB measurements obtained simultaneously at site $\mathrm{T} 0$ and site $\mathrm{T} 1$ for cloudless days are shown in Fig. 11 as a function of solar zenith angle (SZA). This ratio of measured UVB at T0 to UVB at T1 increases dramatically at high SZAs. At high SZAs, when the sun is close to the horizon, the optical path is sufficiently long that the majority of radiation measured by the RB meters is from the diffuse radiation field. The ratio of direct to diffuse insolation measured by the RB meter is 1.3 at a SZA of $20 \mathrm{deg}$. and reaches 0.1 at an SZA of 70 deg. (Granger et al., 1993). Therefore, since magnitude of the ratio of the UVB radiation at both sites is so strongly tied to the SZA, the data shown in Fig. 11 suggests that the diffuse radiation field at site T0 is much larger than that at site $\mathrm{T} 1$.

The aerosol scattering values measured by the threewavelength nephelometer located at site $\mathrm{T} 0$ were used to calculate the average aerosol scattering Ångstrom coefficient $\left(\alpha_{s}\right)$. The Ångstrom coefficient for aerosol scattering is dependent on the particle size distribution with higher values $\left(\alpha_{s}>1\right)$ typically observed for accumulation mode particles $\left(0.1-2\right.$ micron diameter) and lower values $\left(\alpha_{s} \approx 0\right)$ for coarse mode particles ( $>2$ micron) (Hand et al., 2004). The values calculated for the fine mode particles at site $\mathrm{T} 0$ ranged from

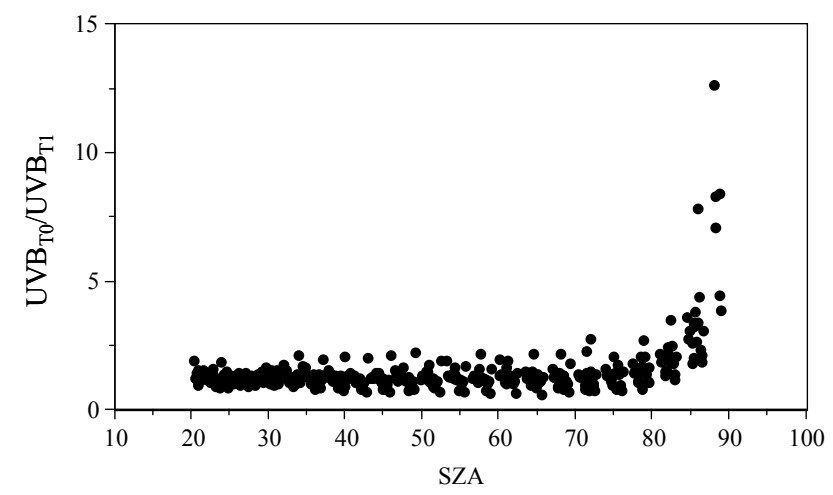

Fig. 11. Ratio of broadband UVB measured at sites T0 and T1 on days without rain events as a function of solar zenith angle (SZA) during the MILAGRO field campaign.

0.93 to 1.30 with an average of 1.11 over the entire study period. This corresponds to an average effective particle radius of 0.3 micron. (O'Niell and Royer, 1993; Lenoble and Brogniez, 1985). The direction of light scattered by particles is also dependent on the size of the particle. This is described by the particle scattering asymmetry factor $(g)$. Mie scattering theory predicts that particles that approach the same size as that of the wavelength of the incoming radiation will scatter the radiation most favorably toward the forward direction. The dominant particle size of the fine mode particles at site T0, as determined by the Angstrom coefficient for scattering, is 0.3 micron $(300 \mathrm{~nm})$, which is of a similar size as the incoming UVB radiation. Therefore the UVB spectral range will be scattered most efficiently toward this forward direction by these fine mode particles. In addition, the Ångstrom scattering exponent of 1.1 corresponds to a $g$ of 0.7 (Lenoble and Brogniez, 1985), which implies that the aerosol scattering intensity will be peaked $45 \mathrm{deg}$. toward the forward direction. Therefore, the predominance of highly scattering submicron aerosols at $\mathrm{T} 0$ results in a larger amount of diffusely scattered UVB radiation and a higher UVB intensity at ground level than was observed at site T1.

The presence of highly absorbing fine mode aerosols in the Mexico City area, as indicated by the low SSAs, are expected to reduce the UV flux at ground level and therefore to reduce the photochemical production of oxidants such as ozone (Dickerson et al., 1997; Castro et al., 2001). However, as seen in Figs. 10 and 11, the presence of fine mode scattering aerosols in the boundary layer that approach the same size as the wavelength of the incoming UV radiation may also increase the UV flux at ground level due to their ability to strongly scatter light towards the forward direction and this increase in UVB flux also leads to an increase in photochemical oxidant production (Dickerson et al., 1997). Therefore, the larger UVB radiation measured at site T0 than at site $\mathrm{T} 1$ helps to explain the high levels of photochemical 
activity observed in the Mexico City area during MILAGRO, despite the reduction in UVB anticipated from the presence of light absorbing species (Thompson et al., 2008; Stephens et al., 2008; Shim et al., 2008; Shon et al., 2008; Dusanter et al., 2008; Wood et al., 2008).

\section{Conclusions}

Measurements of fine mode aerosol absorption and scattering were obtained in Mexico City at site T0 located in the northern part of Mexico City at the IMP (Instituto Mexicano del Petróleo) laboratories and for site T1 located at the Technical University of Tecamac, $29 \mathrm{~km}$ northwest of T0. Hourly averages of aerosol absorption at $550 \mathrm{~nm}$ was similar at both sites, ranging from $7-107 \mathrm{Mm}^{-1}$ with an average of $37 \mathrm{Mm}^{-1}$ at T0; and from 3-147 $\mathrm{Mm}^{-1}$ with an average of $27 \mathrm{Mm}^{-1}$ at T1. Aerosol scattering measured at $550 \mathrm{~nm}$ at $\mathrm{T} 0$ ranged from $16-344 \mathrm{Mm}^{-1}$ with an average of $105 \mathrm{Mm}^{-1}$; while the aerosol scattering values at $\mathrm{T} 1$ were much lower than at T0 ranging from $2-136 \mathrm{Mm}^{-1}$ with an average of $53 \mathrm{Mm}^{-1}$. The maximum scattering values at site T0 occurred $2 \mathrm{~h}$ later than the maximum scattering values seen at $\mathrm{T} 1$ and $4 \mathrm{~h}$ later than the peak aerosol absorption values at either site. This suggests that the high aerosol scattering values measured at $\mathrm{T} 0$ were primarily due to rapid secondary aerosol formation in the city, while the lower aerosol scattering values at $\mathrm{T} 1$ were controlled primarily by changes in the boundary layer height in the early morning.

Fine mode aerosol SSAs were calculated at $550 \mathrm{~nm}$ for both sites using these data. The lower aerosol scattering values result in lower values for aerosol SSA at T1. The SSAs at T0 ranged from $0.47-0.92$ with an average of 0.73 while SSAs at $\mathrm{T} 1$ ranged from $0.35-0.86$ with an average 0.68 . The low SSA determined for the fine mode aerosols indicate the presence of highly absorbing fine mode aerosols in the lower atmosphere. These fine mode aerosols will have a much slower settling velocity $(0.3-60 \mathrm{~cm} / \mathrm{h})$ than the more highly scattering coarse mode aerosols $(60-1000 \mathrm{~cm} / \mathrm{h})$ and will be transported more readily from the Mexico City basin into the surrounding regions (Finlayson-Pitts and Pitts, 2000). The absorption of solar radiation by these highly absorbing fine mode aerosols in the lower atmosphere will result in a heating of the particles and a significant local warming of the boundary layer (Hermann and Hanel, 1997; Ramanathan and Carmichael, 2008). This can result in an increase in the convective available potential energy of the boundary layer and a large scale rising motion over time (Chung and Zhang, 2004) and may help to explain the rapid increase in the boundary layer height observed in past studies in this area (Fast and Zhong, 1998; Whiteman et al., 2000; Shaw et al., 2008). Therefore, studies of boundary layer meteorology processes need to consider absorbing aerosol species when calculating heating rates (Fast and Zhong, 1998; Whiteman et al., 2000).
Comparisons of aerosol absorption averaged over the daylight hours with back trajectories reported by Doran et al. (2007) showed no clear correlation with transport from the Mexico City area, indicating a local source of absorbing aerosols at site T1, as suggested earlier (Doran et al., 2007). Similar comparisons of scattering measurements averaged over the daylight hours also do not seem to show a general trend of major effects on aerosol scattering at $\mathrm{T} 1$ due to transport from Mexico City except for possibly day 81 (22 March). Day 81 was identified as having favorable conditions for transport from site T0 to site T1 (Doran et al., 2007) and that day showed high scattering values for both sites.

Broadband UVB intensity was higher at site T0, with an average of $64 \mu \mathrm{W} / \mathrm{cm}^{2}$ and a range of $50-70 \mu \mathrm{W} / \mathrm{cm}^{2}$ at solar noon, than at site $\mathrm{T} 1$, which had an average of $54 \mu \mathrm{W} / \mathrm{cm}^{2}$ and a range of $48-58 \mu \mathrm{W} / \mathrm{cm}^{2}$ at solar noon. Comparisons of modeled UVB intensities with the simultaneous UVB measurements obtained at site $\mathrm{T} 0$ and at site $\mathrm{T} 1$ for cloudless days imply a larger diffuse radiation field at site T0 than at site T1. The determination of aerosol scattering Ångstrom coefficients at $\mathrm{T} 0$ suggests the predominance of aerosols at $\mathrm{T} 0$ in the size range of 0.3 micron. This results in aerosol scattering peaked $45 \mathrm{deg}$. toward the forward direction leading to the enhanced diffuse radiation at T0. This enhanced diffuse UVB radiation would help to explain the significant photochemistry observed in the Mexico City area during MILAGRO, despite the reduction in UVB anticipated from the high levels of light absorbing aerosol species (Thompson et al., 2008; Stephens et al., 2008; Shim et al., 2008; Shon et al., 2008; Dusanter et al., 2008; Wood et al., 2008).

The results of this study confirm that the Mexico City megacity environment has significant levels of fine mode absorbing aerosols. The high loadings of BC aerosols from fossil fuel emissions in the urban environment along with biomass burning contributions contribute to significant aerosol absorption, which will lead to local warming in the boundary layer at both the urban and regional sites. The presence of these high concentrations of absorbing aerosols in the urban area will contribute to the urban heat island effects and the transport of these absorbing aerosols into the surrounding areas will result in a positive climate forcing and an overall warming effect in the region.

Acknowledgements. This work was conducted as part of the Department of Energy's Atmospheric Science Program as part of the Megacity Aerosol Experiment - Mexico City, and as part of the MCMA2006 study during MILAGRO. This research was supported by the Office of Science (BER), US Department of Energy Grant No. DE-FG02-07ER64329 and the Mexican Government through SEMARNAT (FOSEMARNAT-2004-01-116) and the Metropolitan Environmental Commission. We wish to thank Mr. Rick Petty and Ashley Willamson of OBER for their continuing encouragement. We also wish to thank Mexican scientists and students from the Instituto Mexicano del Petróleo (IMP) and CENICA, for their assistance, and also to M. I. Saavedra from CCA, UNAM. Thanks also to Neil Sturchio, Ms. Linnea Heraty, and Ms. Nancy Martinez 
of the University of Illinois at Chicago for their assistance in obtaining TC measurements reported here, and to Luisa Molina and Sasha Madronich for their organizational assistance with MILAGRO.

Edited by: L. Molina

\section{References}

Aiken, A. C., DeCarlo, P. F., Kroll, J. H., Worsnop, D. R., Huffman, J. A., Docherty, K. S., Ulbrich, I. M., Mohr, C. Kimmel, J. R., Sueper, D., Sun, Y., Zhang, Q., Trimborn, A., Northway, M., Zieman, P. J., Canagaratna, M. B., Onash, T. B., Alfarra, M. R., Prevot, A. S. H., Dommen, J., Duplissy, J., Metzger, A., Baltensperger, U., and Jimenz, J. L. O/C and M/OC ratios of primary, secondary, and ambient organic aerosols with high resolution time-of-flight aerosol mass spectrometry, Environ. Sci. Technol., 42, 4478-4485, 2008.

Anderson, T. L. and Ogren, J. A.: Determining aerosol radiative properties using the TSI 3563 integrating nephelometer, Aerosol Sci. Tech., 29, 57-69, 1998.

Andreae, M. O. and Gelencsér, A.: Black carbon or brown carbon? The nature of light-absorbing carbonaceous aerosols, Atmos. Chem. Phys., 6, 3131-3148, 2006, http://www.atmos-chem-phys.net/6/3131/2006/.

Arnott, W. P., Hamasha, K., Moosmuller, H., Sheridan, P. J., and Ogren, J. A.: Towards aerosol light-absorption measurements with a 7-wavelength aethalometer: Evaluation with a photoacoustic instrument and 3-wavelength nephelometer, Aerosol Sci. Tech., 39, 17-29, 2005.

Ban-Weiss, G. A., McLaughlin, J. P., Harley, R. A., Lunden, M. M., Kirchstetter, T. W., Kean, A. J., Strawa, A. W., Stevenson, E. D., and Kendall, G. R.: Long-term changes in emissions of nitrogen oxides and particulate matter from on-road gasoline and diesel vehicles, Atmos. Environ., 42, 220-232, 2008.

Barnard, J. C., Kassianov, E. I., Ackerman, T. P., Johnson, K., Zuberi, B., Molina, L. T., and Molina, M. J.: Estimation of a "radiatively correct" black carbon specific absorption during the Mexico City Metropolitan Area (MCMA) 2003 field campaign, Atmos. Chem. Phys., 7, 1645-1655, 2007, http://www.atmos-chem-phys.net/7/1645/2007/.

Barnard, J. C., Volkamer, R., and Kassianov, E. I.: Estimation of the mass absorption cross section of the organic carbon component of aerosols in the Mexico City Metropolitan Area, Atmos. Chem. Phys., 8, 6665-6679, 2008, http://www.atmos-chem-phys.net/8/6665/2008/.

Barth, M. C. and Church, A. T.Regional and global distributions and lifetimes of sulfate aerosols from Mexico City and southeast China, J. Geophys. Res., 104, 30231-30239, 1999.

Baumgardner, D., Kok, G. L., and Raga, G. B.: On the diurnal variability of particle properties related to light absorbing carbon in Mexico City, Atmos. Chem. Phys., 7, 2517-2526, 2007, http://www.atmos-chem-phys.net/7/2517/2007/.

Bergstrom, R. W.: Extinction and absorption coefficients of the atmospheric aerosol as a function of particle size, Beitraege zur Physik der Atmosphaere, 46, 223-234, 1973.

Bergstrom, R. W., Russell, P. B., and Hignett, P.: Wavelength dependence of the absorption of black carbon particles: Predictions and results from the TARFOX experiment and implications for the aerosol single scattering albedo, J. Atmos. Sci., 59, 567-577, 2002.

Bond, T. C., Anderson, T. L., and Campbell, D.: Calibration and intercomparison of filter-based measurements of visible light absorption by aerosols, Aerosol Sci. Tech., 30, 582-600, 1999.

Bond, T. C. and Bergstrom, R. W.: Light absorption by carbonaceous particles: An investigative review, Aerosol Sci. Tech., 40, 27-67, 2006.

Bond, T. C., Habib, G., and Bergstrom, R. W.: Limitations in the enhancement of visible light absorption due to mixing state, J. Geophys. Res., 111, D20211, doi:10.1029/2006JD007315, 2006.

CAM: Programa para Mejorar la Calidad del aire de la Zona Metropolitana del Valle de Mexico 2002-2010, Capitulo 2, La Zona Metropolitana del Valle de Mexico, 25 pp., online available at: (http://www.paot.org.mx/centro/libros/proaire/ cap02.pdf), last access: January 2009, 2002.

Carabalí, G.: Caracterización morfológica, óptica y química de partículas muestreadas en el sitio T1 de la campaña MILAGRO, Tesis de Maestría, Universidad Nacional Autónoma de México, México, 2008..

Castro, T., Madronich, S., Rivale, S., Muhlia, A., and Mar, B.: The influence of aerosols on photochemical smog in Mexico City, Atmos. Environ., 35, 1765-1772, 2001.

Charlson, R. J., Schwartz, S. E., Hales, J. M., Cess, R. D., Coakley Jr., J. A., Hansen, J. E., and Hoffman, D. J.: Climate forcing by anthropogenic aerosols, Science, 255, 423-430, 1992.

Chow, J. C., Watson, J. G., Pritchett, L. C., Pierson, W. R., Frazier, C. A., and Purcell, R. G.: The DRI thermal/optical reflectance carbon analysis system: description, evaluation, and applications in US air quality studies, Atmos. Environ., 27, 1185-1201, 1993.

Chow, J. C., Watson, J. G., Edgerton, S. A., and Vega, E.: Spacial differences in outdoor $\mathrm{PM}_{10}$ mass and aerosol composition in Mexico City, J. Air Waste Manage., 52, 423-434, 2001.

Chow, J. C., Watson, J. G., Edgerton, S. A., and Vega, E.: Chemical composition of $\mathrm{PM}_{2.5}$ and $\mathrm{PM}_{10}$ in Mexico City during winter 1997, Sci. Total Environ., 287, 177-201, 2002.

Chung, C. E. and Zhang, G. J.: Impact of absorbing aerosol on precipitation: Dynamic aspects in association with convective available potential energy and convective parameterization closure and dependence on aerosol heating profile, J. Geophys. Res., 109, D22103, doi:10.1029/2004JD004726, 2004.

Chung, S. H. and Seinfeld, J. H.: Climate response of direct radiative forcing of anthropogenic black carbon, J. Geophys. Res., 110, D11102, doi:10.1029/2004JD005441, 2005.

Clarke, A. D.: Aerosol light absorption by soot in remote environments, Aerosol Sci. Tech., 10, 161-171, 1989.

DeCarlo, P. F., Dunlea, E. J., Kimmel, J. R., Aiken, A. C., Sueper, D., Crounse, J., Wennberg, P. O., Emmons, L., Shinozuka, Y., Clarke, A., Zhou, J., Tomlinson, J., Collins, D. R., Knapp, D., Weinheimer, A. J., Montzka, D. D., Campos, T., and Jimenez, J. L.: Fast airborne aerosol size and chemistry measurements above Mexico City and Central Mexico during the MILAGRO campaign, Atmos. Chem. Phys., 8, 4027-4048, 2008, http://www.atmos-chem-phys.net/8/4027/2008/.

de Foy, B., Varela, J. R., Molina, L. T., and Molina, M. J.: Rapid ventilation of the Mexico City basin and regional fate of the urban plume, Atmos. Chem. Phys., 6, 2321-2335, 2006, http://www.atmos-chem-phys.net/6/2321/2006/. 
de Foy, B., Fast, J. D., Paech, S. J., Phillips, D., Walters, J. T., Coulter, R. L., Martin, T. J., Pekour, M. S., Shaw, W. J., Kastendeuch, P. P., Marley, N. A., Retama, A., and Molina, L. T.: Basinscale wind transport during the MILAGRO field campaign and comparison to climatology using cluster analysis, Atmos. Chem. Phys., 8, 1209-1224, 2008,

http://www.atmos-chem-phys.net/8/1209/2008/.

DeLuisi, J., Wendell, J., and Kreiner, F.: An examination of the spectral response characteristics of seven Robertson-Berger meters after long-term field use, Photochem. Photobiol., 56, 115122, 1992

Dickerson, R. R., Kondragunta, S., Stenchikov, G., Civerolo, K. L., Doddridge, B. G., and Holben, B. N.: The impact of aerosols on solar ultraviolet radiation and photochemical smog, Science, 31, 827-830, 1997.

Doran, J. C., Abbott, S., Archuleta, J., Bian, X., Chow, J., Coulter, R. L., de Wekker, S. F. J., Edgerton, S., Elliott, S., Fernandez, A., Fast, J. D., Hubbe, J. M., King, C., Langley, D., Leach, J., Lee, J. T., Martin, T. J., Martinez, D., Martinez, J. L., Mercado, G., Mora, V., Mulhearn, M., Pena, J. L., Petty, R., Porch, W., Russell, C., Salas, R., Shannon, J. D., Shaw, W. J., Sosa, G., Tellier, L., Templeman, B., Watson, J. G., White, R., Whiteman, C .D., and Wolfe, D.: The IMADA-AVER boundary layer experiment in the Mexico City area, B. Am. Meteorol. Soc., 79, 2497-2508, 1998.

Doran, J. C., Barnard, J. C., Arnott, W. P., Cary, R., Coulter, R., Fast, J. D., Kassianov, E. I., Kleinman, L., Laulainen, N. S., Martin, T., Paredes-Miranda, G., Pekour, M. S., Shaw, W. J., Smith, D. F., Springston, S. R., and Yu, X.-Y.: The T1-T2 study: evolution of aerosol properties downwind of Mexico City, Atmos. Chem. Phys., 7, 1585-1598, 2007,

http://www.atmos-chem-phys.net/7/1585/2007/.

Doran, J. C.: Corrigendum to "The T1-T2 study: evolution of aerosol properties downwind of Mexico City", Atmos. Chem. Phys., 7, 1585-1598, 2007,

http://www.atmos-chem-phys.net/7/1585/2007/.

Doran, J. C., Fast, J. D., Barnard, J. C., Laskin, A., Desyaterik, Y., and Gilles, M. K.: Applications of lagrangian dispersion modeling to the analysis of changes in the specific absorption of elemental carbon, Atmos. Chem. Phys., 8, 1377-1389, 2008, http://www.atmos-chem-phys.net/8/1377/2008/.

Dua, S. K., Hopke, P. K., and Raunemaa, T.: Hygroscopicity of diesel aerosols Water Air Soil Poll., 112, 247-257, 1999.

Dubovik, O., Holben, B. N., Kaufman, Y. J., Yamasoe, M., Smirnov, A., Tanre, D., and Slutsker, I.: Single scattering albedo of smoke retrieved from the sky radiance and solar transmittance measured from ground, J. Geophys. Res., 103, 31903-31923, 1998.

Dusanter, S., Vimal, D., Stevens, P. S., Volkamer, R., and Molina, L. T.: Measurements of $\mathrm{OH}$ and $\mathrm{HO}_{2}$ concentrations during the MCMA-2006 field campaign - Part 1: Deployment of the Indiana University laser-induced fluorescence instrument, Atmos. Chem. Phys. Discuss., 8, 13689-13739, 2008,

http://www.atmos-chem-phys-discuss.net/8/13689/2008/.

Eidels-Dubovoi, S.: Aerosol impacts on visible light extinction in the atmosphere of Mexico City, Sci. Total Environ., 287, 213220,2002

Fast, J. D. and Zhong, S.: Meteorological factors associated with inhomogeneous ozone concentrations within the Mexico City basin, J. Geophys. Res., 103, 18927-18946, 1998.

Fast, J. D., de Foy, B., Acevedo Rosas, F., Caetano, E., Carmichael,
G., Emmons, L., McKenna, D., Mena, M., Skamarock, W., Tie, X., Coulter, R. L., Barnard, J. C., Wiedinmyer, C., and Madronich, S.: A meteorological overview of the MILAGRO field campaigns, Atmos. Chem. Phys., 7, 2233-2257, 2007, http://www.atmos-chem-phys.net/7/2233/2007/.

Finlayson-Pitts, B. J. and Pitts Jr., J. N.: Chemistry of the Upper and Lower Atmosphere, chapter 9, Academic Press, 349-374, 2000.

Frederick, J. E. and Lubin, D.: The budget of biologically active radiation in the earth-atmosphere system, J. Geophys. Res., 93, 3825-3832, 1988.

Gaffney, J. S., Tanner, R. L., and Phillips, M.: Separating carbonaceous aerosol source terms using thermal evolution, carbon isotopic measurements, and C/N/S determinations, Sci. Total Environ., 36, 53-60, 1984.

Gaffney, J. S. and Marley, N. A.: Uncertainties in climate change predictions: Aerosol effects, Atmos. Environ., 32, 2873-2874, 1998.

Gaffney, J. S., Marley, N. A., Cunningham, M. M., and Doskey, P. V.: Measurements of peroxyacyl nitrates (PANs) in Mexico City: Implications for megacity air quality impacts on regional scales, Atmos. Environ., 33, 5003-5012, 1999.

Gaffney, J. S., Marley, N. A., Drayton, P. J., Doskey, P. V., Kotamarthi, V. R., Cunningham, M. M., Baird, J. C. Dintaman, J., and Hart, H. L.: Field observations of regional and urban impacts on $\mathrm{NO}_{2}$, Ozone, UV-B, and nitrate radical production rates: Nocturnal urban plumes and regional smoke effects, Atmos. Environ., 36, 825-833, 2002.

Gaffney, J. S. and Marley, N. A.: The importance of the chemical and physical properties of aerosols in determining their transport and residence times in the troposphere, Chapter 14, in: Urban Aerosols and Their Impacts: Lessons Learned from the World Trade Center Tragedy, edited by: Gaffney, J. S. and N. A., Marley, ACS Symposium Book 919, Oxford University Press, 286300, 2005.

Gaffney, J. S., Marley, N. A., Tackett, M., Stuchio, N., Heraty, L., Martinez, N. Hardy, K., and Guilderson, T.: Biogenic carbon dominance based on ${ }^{13} \mathrm{C} /{ }^{12} \mathrm{C}$ and ${ }^{14} \mathrm{C}$ measurements of total carbon at T-0 and T- 1 sites during MILAGRO, 88th National Meeting of the American Meteorological Society, Tenth Conference on Atmospheric Chemistry, Conference Proceedings Volume, Paper J1.1, 5 pp., online availabe at: http://ams.confex. com/ams/pdfpapers/131852.pdf, 2008.

Granger, R. G., Basher, R. E., and McKenzie, R. L.: UV-B Robertson-Berger meter characterization and field calibration, Appl. Optics, 32, 343-349, 1993.

Hand, J. L., Kreidenweis, S. M., Slusser, J., and Scott, G.: Comparison of aerosol optical properties derived from Sun photometry to estimates inferred from surface measurements in Big Bend National Park, Texas, Atmos. Environ., 38, 6813-6821, 2004.

Hansen, A. D. A., Rosen, H., and Novakov, T.: Real-time measurement of the absorption coefficient of aerosol particles, Appl Optics, 21, 3060-3062, 1982.

Hennigan, C. J., Sullivan, A. P., Fountoukis, C. I., Nenes, A., Hecobian, A., Vargas, O., Peltier, R. E., Case Hanks, A. T., Huey, L. G., Lefer, B. L., Russell, A. G., and Weber, R. J.: On the volatility and production mechanisms of newly formed nitrate and water soluble organic aerosol in Mexico City, Atmos. Chem. Phys., 8, 3761-3768, 2008,

http://www.atmos-chem-phys.net/8/3761/2008/. 
Hermann, P. and Hanel, G.: Wintertime optical properties of atmospheric particles and weather, Atmos. Environ., 24, 4053-4062, 1997.

Hermann, M., Stratmann, M., Wilck, M., and Wiedensohler, A.: Sampling characteristics of an aircraft-borne aerosol inlet system, J. Am. Meterol. Soc., 7-19, 2001.

Hitzenberger, R. and Puxbaum, H.: Comparisons of the measured and calculated specific absorption coefficients for urban aerosol samples in Vienna, Aerosol Sci. Technol., 18, 323-345, 1993.

Hoffer, A., Gelencsér, A., Guyon, P., Kiss, G., Schmid, O., Frank, G. P., Artaxo, P., and Andreae, M. O.: Optical properties of humic-like substances (HULIS) in biomass-burning aerosols, Atmos. Chem. Phys., 6, 3563-3570, 2006,

http://www.atmos-chem-phys.net/6/3563/2006/.

Horvath, H., Catalan, L., and Trier, A. A.: study of the aerosol of Santiago De Chile III: Light absorbing measurements, Atmos. Environ., 31, 3737-3744, 1997.

Jacobson, M. Z.: Global direct radiative forcing due to multicomponent anthropogenic and natural aerosols, J. Geophys. Res., 106, 1551-1568, 2001.

Jacobson, M. Z.: Control of fossil fuel particulate black carbon and organic matter, possibly the most effective method of slowing global warming, J. Geophys. Res., 107, ACH 16-1-16-22, doi:10.1029/2001JD001376, 2002.

Jacobson, M. Z.: Climate response of fossil fuel and biofuel soot, accounting for soot's feedback to snow and sea ice albedo and emissivity, J. Geophys. Res., 109, D21201, doi:10.1029/2004JD004945, 2004.

Kirchstetter, T. W., Novakov, T., and Hobbs, P. V.: Evidence that the spectral dependence of light absorption by aerosols is affected by organic carbon, J. Geophys. Res., 109, D21208, doi:10.1029/2004JD004999, 2004.

Kleinman, L. I., Springston, S. R., Daum, P. H., Lee, Y.-N., Nunnermacker, L. J., Senum, G. I., Wang, J., Weinstein-Lloyd, J., Alexander, M. L., Hubbe, J., Ortega, J., Canagaratna, M. R., and Jayne, J.: The time evolution of aerosol composition over the Mexico City plateau, Atmos. Chem. Phys., 8, 1559-1575, 2008, http://www.atmos-chem-phys.net/8/1559/2008/.

Lenoble, J. and Brogniez, C.: Information on stratospheric aerosol characteristics contained in the SAGE satellite multiwavelength extinction measurements, Appl. Optics, 24, 1054-1063, 1985.

Marley, N. A., Gaffney, J. S., Drayton, P. J., Cunningham, M. M., Orlandini, K. A., and Paode, R.: Measurement of ${ }^{210} \mathrm{~Pb},{ }^{210} \mathrm{Po}$, and ${ }^{210} \mathrm{Bi}$ in size-fractionated atmospheric aerosols: An estimate of fine-aerosol residence times, Aerosol Sci. Tech., 32, 569-583, 2000 .

Marley, N. A., Gaffney, J. S., Ramos-Villegas, R., and Cárdenas González, B.: Comparison of measurements of peroxyacyl nitrates and primary carbonaceous aerosol concentrations in Mexico City determined in 1997 and 2003, Atmos. Chem. Phys., 7, 2277-2285, 2007,

http://www.atmos-chem-phys.net/7/2277/2007/.

Marley, N. A. and Gaffney, J. S.: The impact of rain events on aerosol optical properties: Mexico City 2003 and 2006, EOS Transactions AGU, 88(23), Joint Assembly Supplement, Abstract A41E-03, 2007.

Marley, N. A., Gaffney, J. S., Tackett, M. J., Sturchio, N. C., Heraty, L., Martinez, N., Hardy, K. D., Machany-Rivera, A., Guilderson, T., MacMillan, A., and Steelman, K.: The impact of biogenic carbon emissions on aerosol absorption in Mexico City, Atmos. Chem. Phys. Discuss., 8, 18499-18530, 2008,

http://www.atmos-chem-phys-discuss.net/8/18499/2008/.

McKinlay, A. and Diffy, B. L.: A reference action spectrum for ultraviolet induced erythema in human skin, in: Human exposure to ultraviolet radiation: Risks and regulations, edited by: Passchler, W. R. and Bosnajokovic, B. F. M., Elsevier Science Publishers, Amsterdam, The Netherlands, 83-87, 1987.

Molina, L. T. and Molina, M. J.: Air quality impacts: Local and global concern, Chapter 1, in: Air quality in the Mexico Megacity, An integrated assessment, edited by: Molina, L. T., Molina, M. J., Kluwer Academic, The Netherlands, 2002.

Molina, L. T., Kolb, C. E., de Foy, B., Lamb, B. K., Brune, W. H., Jimenez, J. L., Ramos-Villegas, R., Sarmiento, J., ParamoFigueroa, V. H., Cardenas, B., Gutierrez-Avedoy, V., and Molina, M. J.: Air quality in North America's most populous city overview of the MCMA-2003 campaign, Atmos. Chem. Phys., 7, 2447-2473, 2007, http://www.atmos-chem-phys.net/7/2447/2007/.

O'Niell, N. and Royer, A.: Extraction of bimodal aerosol-size distribution radii from spectral and angular slope (Angstrom) coefficients, Appl. Optics, 32, 1642-1645, 1993.

Paredes-Miranda, G., Arnott, W. P., Jimenez, J. L., Aiken, A. C., Gaffney, J. S., and Marley, N. A.: Primary and secondary contributions to aerosol light scattering and absorption in Mexico City during the MILAGRO 2006 campaign, Atmos. Chem. Phys. Discuss., 8, 16951-16979, 2008,

http://www.atmos-chem-phys-discuss.net/8/16951/2008/.

Patterson, E. M. and McMahon, C. K.: Absorption characteristics of forest fire particulate matter, Atmos. Environ., 18, 2541-2551, 1984.

Petzold, A., Schloesser, H., Sheridan, P. J., Arnott, W. P., Ogren, J. A., and Virkkula, A.: Evaluation of multiangle absorption photometry for measuring aerosol light absorption, Aerosol Sci. Tech., 39, 40-51, 2005.

Pósfai, M., Anderson, J. R., Buseck, P. R., and Sievering, H.: Soot and sulfate aerosol particles in the remote marine troposphere, J. Geophys. Res., 104, 21685-21683, 1999.

Raga, G. B., Castro, T., and Baumgardner, D.: The impact of megacity pollution on local climate and implications for the regional environment: Mexico City, Atmos. Environ., 35, 18051811, 2001a.

Raga, G. B., Baumgardner, D., Castro, T., Martìnez-Arroyo, A., and Navarro-González, R.: Mexico City air quality: a qualitative review of gas and aerosol measurements (1960-2000), Atmos. Environ., 35, 4041-4058, 2001 b.

Ramanathan, V., Crutzen, P. J., Kiehl, J. T., and Rosenfeld, D.: Aerosols, climate, and the hydrological cycle, Science, 7, 21192124, 2001.

Ramanathan, V., Chung, C., Kim, D., Bettge, T., Buja, L., Kiel, J. T., Washington, W. M., Fu, Q., Sikka, D. R., and Wild, M.: Atmospheric brown clouds: Impacts on South Asain climate and hydrological cycle, P. Natl. Acad. Sci. USA, 102, 5326-5333, 2005.

Ramanathan, V. and Carmichael, G.: Global and regional climate changes due to black carbon, Nature Geoscience, 1, 221-227, 2008.

Salcedo, D., Onasch, T. B., Dzepina, K., Canagaratna, M. R., Zhang, Q., Huffman, J. A., DeCarlo, P. F., Jayne, J. T., Mor- 
timer, P., Worsnop, D. R., Kolb, C. E., Johnson, K. S., Zuberi, B., Marr, L. C., Volkamer, R., Molina, L. T., Molina, M. J., Cardenas, B., Bernabé, R. M., Márquez, C., Gaffney, J. S., Marley, N. A., Laskin, A., Shutthanandan, V., Xie, Y., Brune, W., Lesher, R., Shirley, T., and Jimenez, J. L.: Characterization of ambient aerosols in Mexico City during the MCMA-2003 campaign with Aerosol Mass Spectrometry: results from the CENICA Supersite, Atmos. Chem. Phys., 6, 925-946, 2006, http://www.atmos-chem-phys.net/6/925/2006/.

Schmid, O., Artaxo, P., Arnott, W. P., Chand, D., Gatti, L. V., Frank, G. P., Hoffer, A., Schnaiter, M., and Andreae, M. O.: Spectral light absorption by ambient aerosols influenced by biomass burning in the Amazon Basin. I: Comparison and field calibration of absorption measurement techniques, Atmos. Chem. Phys., 6, 3443-3462, 2006,

http://www.atmos-chem-phys.net/6/3443/2006/.

Schnaiter, M., Linke, C., Möhler, O., Naumann, K.-H., Saathoff, H., Wagner, R., Schurath, U., and Wehner, B.: Absorption amplification of black carbon internally mixed with secondary organic aerosol, J. Geophys. Res., 110, D19204, doi:10.1029/2005JD006046, 2005.

Schuster, G. L., Dubovik, O., Holben, B. N., and Clothiaux, E. E.: Inferring black carbon content and specific absorption from AERONET retrievals, J. Geophys. Res., 101, D10S17, doi:10.1029/2004JD006328, 2005.

Schwartz, S. E. and Buseck, P. R.: Absorbing phenomena, Science, 288, 989-990, 2000.

Shaw, W. J., Pekour, M. S., Coulter, R. L., Martin, T. J., and Walters, J. T.: The daytime mixing layer observed by radiosonde, profiler, and lidar during MILAGRO, Atmos. Chem. Phys. Discuss., 7, 15025-15065, 2007, http://www.atmos-chem-phys-discuss.net/7/15025/2007/.

Shim, C., Li, Q., Luo, M., Kulawik, S., Worden, H., Worden, J., Eldering, A., Diskin, G., Sachse, G., Weinheimer, A., Knapp, D., Montzca, D., and Campos, T.: Characterizing mega-city pollution with TES $\mathrm{O}_{3}$ and $\mathrm{CO}$ measurements, Atmos. Chem. Phys. Discuss., 7, 15189-15212, 2007,

http://www.atmos-chem-phys-discuss.net/7/15189/2007/.
Shon, Z.-H., Madronich, S., Song, S.-K., Flocke, F. M., Knapp, D. J., Anderson, R. S., Shetter, R. E., Cantrell, C. A., Hall, S. R., and Tie, X.: Characteristics of the $\mathrm{NO}-\mathrm{NO}_{2}-\mathrm{O}_{3}$ system in different chemical regimes during the MIRAGE-Mex field campaign, Atmos. Chem. Phys., 8, 7153-7164, 2008, http://www.atmos-chem-phys.net/8/7153/2008/.

Stephens, S., Madronich, S., Wu, F., Olson, J. B., Ramos, R., Retama, A., and Muñoz, R.: Weekly patterns of Mxico City's surface concentrations of $\mathrm{CO}, \mathrm{NO}_{\mathrm{x}}, \mathrm{PM}_{10}$ and $\mathrm{O}_{3}$ during 19862007, Atmos. Chem. Phys., 8, 5313-5325, 2008, http://www.atmos-chem-phys.net/8/5313/2008/.

Stone, E. A., Snyder, D. C., Sheesley, R. J., Sullivan, A. P., Weber, R. J., and Schauer, J. J.: Source apportionment of fine organic aerosol in Mexico City during the MILAGRO experiment 2006, Atmos. Chem. Phys., 8, 1249-1259, 2008, http://www.atmos-chem-phys.net/8/1249/2008/.

Swap, R. J., Annegarn, H. J., Suttes, J. T., King, M. D., Platnick, S., Privette, J. L., and Scholes, R. J.: Africa burning: A thematic analysis of the Southern African Regional Science Initiative (SAFARI 2000), J. Geophys. Res./ 108(D13), 8465, doi10.1029/2003JD003747, 2003.

Tanner, R. L., Gaffney, J. S., and Phillips, M. F.: Determination of Organic and Elemental Carbon in Atmospheric Aerosol Samples by Thermal Evolution, Anal. Chem., 54, 1627-1630, 1982.

Thompson, A. M., Yorks, J. E., Miller, S. K., Witte, J. C., Dougherty, K. M., Morris, G. A., Baumgardner, D., Ladino, L., and Rappenglück, B.: Tropospheric ozone sources and wave activity over Mexico City and Houston during MILAGRO/Intercontinental Transport Experiment (INTEX-B) Ozonesonde Network Study, 2006 (IONS-06), Atmos. Chem. Phys., 8, 5113-5125, 2008, http://www.atmos-chem-phys.net/8/5113/2008/. 
UNEP/WHO (United Nations Environmental Program/World Health Organization), Urban Air Pollution in Megacities of the World, Blackwell Publisher, Oxford, UK, 1992.

Vega, E., Reyes, E., Ruiz, H., Garcia, J., Sanchez, G., MartinezVilla, G., Gonzalez, U., Chow, J. C., and Watson, J. G.: Analysis of $\mathrm{PM}_{2.5}$ and $\mathrm{PM}_{10}$ in the atmosphere of Mexico City during 2000-2002, J. Air Waste Manage., 54, 786-798, 2004.

Volkamer, R., Jimenez, J. L., San Martini, F., Dzpina, F., Zhang, Q., Salcedo, D., Molina, L. T., Worsnop, D. R., and Molina, M. J.: Secondary organic aerosol formation from anthropogenic air pollution: Rapid and higher than expected, Geophys. Res. Lett., 33, L17811, doi:10.1029/2006GL026899, 2006.

Weatherhead, E. C., Tiao, G. C., Reinsel, G. C., Frederick, J. E., DeLuisi, J. J., Choi, D., and Tam, W.: Analysis of long-term behavior of ultraviolet radiation measured by Robertson-Berger meters at 14 sites in the United States, J. Geophys. Res., 102, 8737-8754, 1997.

Whiteman, C. D., Zhong, S., Bian, X., Fast, J. D., and Doran, J. C.: Boundary layer evolution and regional scale diurnal circulations over the Mexican plateau, J. Geophys. Res., 105, 10081-10102, 2000.

Williams, J., de Reus, M., Krejci, R., Fischer, H., and Ström, J.: Application of the variability-size relationship to atmospheric aerosol studies: estimating aerosol lifetimes and ages, Atmos. Chem. Phys., 2, 133-145, 2002,

http://www.atmos-chem-phys.net/2/133/2002/.

Wood, E. C., Herndon, S. C., Onasch, T. B., Kroll, J. H., Canagaratna, M. R., Kolb, C. E., Worsnop, D. R., Neuman, J. A., Seila, R., Zavala, M., and Knighton, W. B.: Ozone production, nitrogen oxides, and radical budgets in Mexico City: observations from Pico de Tres Padres, Atmos. Chem. Phys. Discuss., 8, 15739-15789, 2008,

http://www.atmos-chem-phys-discuss.net/8/15739/2008/.

Yokelson, R. J., Urbanski, S. P., Atlas, E. L., Toohey, D. W., Alvarado, E. C., Crounse, J. D., Wennberg, P. O., Fisher, M. E., Wold, C. E., Campos, T. L., Adachi, K., Buseck, P. R., and Hao, W. M.: Emissions from forest fires near Mexico City, Atmos. Chem. Phys., 7, 5569-5584, 2007,

http://www.atmos-chem-phys.net/7/5569/2007/.

$\mathrm{Xu}, \mathrm{G}$. and Huang, X.: Calibration of broadband UV radiometers - methodology and uncertainty evaluation, Metrologia, 40, S21S24, 2003. 